\title{
A luta contra a adversidade: notas de pesquisa sobre $o$ mutualismo na Bahia (1832-1930)
}

Aldrin A. S. Castellucci

Resumo: $\mathrm{O}$ artigo faz uma cartografia do associativismo de auxílio mútuo na Bahia entre 1832, quando surgiram as primeiras entidades desse tipo no estado, e 1930, quando a Primeira República entrou em colapso e o Estado brasileiro passou a ter uma atuação mais proeminente na questão securitária e nas relações entre capital e trabalho. Além disso, examina as diferenças existentes no fenômeno, considerando os diversos grupos e classes sociais envolvidos no processo, distinguindo, por exemplo, as associações que agrupavam por meio de identidades sócio-profissionais das que o faziam tendo por base as afinidades e as solidariedades étnico-nacionais.

Palavras-chave: Estado; classe operária; mutualismo.

Abstract: The article maps the associations for mutual assistance in Bahia from 1832, when such type of entities emerged in the state, to 1939, when the First Republic collapsed and the Brazilian government took a firmer stand on social security and the relations between capital and labour. It also examines the differences in the phenomenon taking into consideration the varied groups and social classes involved in the process, making a distinction, for example, between the associations that were formed based on socio-professional identities from those which were based on ethno-national relations and solidarity.

Keywords: State, working class, mutualism

\section{INTRODUÇÃO}

Longe de ser uma criação absolutamente original dos brasileiros, o mutualismo foi um fenômeno global, conforme mostrou um estudo comparativo de 1996, no qual foram mapeadas associações de auxílio mútuo em países com histórias diversas como, por exemplo, a Grã-Bretanha, Irlanda, Estados Unidos, Canadá, Austrália, Nova Zelândia, França, Itália, Espanha, Portugal, Alemanha, Suíça, Áustria, Hungria, Polônia, Rússia, Bélgica, Holanda, Suécia, Finlândia, China, Índia, Indonésia, México e Chile ${ }^{1}$.

A despeito disso, da mesma forma que ocorrera em inúmeros outros países, durante muito tempo, o mutualismo foi, equivocadamente, visto como uma simples

\footnotetext{
*Universidade do Estado da Bahia - UNEB. aldrin.castellucci@hotmail.com

${ }^{1}$ LINDEN, Marcel van der (ed.). Social security mutualism. The comparative history of mutual benefit societies. Bem/Berlin/Frankfurt/New lork/ Wien: Peter Lang, 1996.
} 
pré-história do movimento sindical e operário brasileiro. Tal concepção só foi superada na década de $1990^{2}$.

De todo modo, o que os estudos mais recentes demonstraram, cabalmente, e é preciso explicitar aqui, é que esse associativismo mutualista conviveu e se expandiu de modo distinto e paralelo aos chamados sindicatos de resistência, criados durante a Primeira República, não tendo nenhuma relação de anterioridade lógica com essas organizações, mesmo por que tinham objetivos diferentes. Enquanto os sindicatos lutavam por salários maiores e melhores condições de trabalho para seus filiados, ou seja, atuavam na esfera da produção, as sociedades de auxílio mútuo faziam gestões no campo da securitização. Como observou Tânia Regina de Luca:

\begin{abstract}
Pode-se contra-argumentar que mesmo não se articulando em torno do processo produtivo elas o tinham como ponto de referência, pois se destinavam a prestar auxílio aos que, por doença, acidente, invalidez ou velhice deixassem de trabalhar, assumindo com isso caráter previdenciário. Isto é correto mas em nada as aproxima dos sindicatos, pelo contrário, distancia. Estes se referem diretamente à relação entre capital e trabalho, entre operários e capitalistas, enquanto os primeiros se dirigiam exatamente aos que saíam da produção, ao âmbito da reprodução da força de trabalho. Seu objetivo era remediar a situação dos trabalhadores inaptos para o processo produtivo, sem maiores preocupações em relação à estrutura social vigente. ${ }^{3}$
\end{abstract}

Uma estatística oficial, de 1917, serve bem para mostrar a extensão e a força do fenômeno que se quer analisar. Por ela, ficamos sabendo que, naquele ano, existiam, pelo menos, 3.505 sociedades de auxílios mútuos e de beneficência no Brasil, com o antigo Distrito Federal ocupando a posição de destaque, com 816 entidades desse tipo. Em seguida, vinham os estados de Minas Gerais (790), São Paulo (744),

\footnotetext{
${ }^{2}$ No Brasil, a ideia de que as sociedades mutualistas teriam sido simples embriões, antecessores diretos dos sindicatos, foi formulada de maneira sistemática no final da década de 1960, pelo sociólogo José Albertino Rodrigues. Cf. RODRIGUES, José Albertino. Sindicato e desenvolvimento no Brasil. São Paulo: Difel, 1968. Porém, aquela já parecia uma ideia pouco aceita por outros cientistas sociais da época, como, por exemplo, Azis Simão que, em 1966, publicou um importante estudo histórico sobre o sindicalismo em São Paulo negando tal tese. Vejamos uma passagem de sua obra acerca do assunto: "As mutuais contribuíram para a emergência do movimento operário, de um modo geral, mas não deram origem ao sindicalismo que apareceu na mesma época. De fato, no arrolamento feito das sociedades de trabalhadores, apenas quatro grêmios daquela espécie precedem o surgimento das ligas operárias propriamente ditas. Estas já deviam ter-se formado como primeiras e tímidas reproduções de modelos associativos elaborados no sindicalismo europeu". SIMÃO, Azis. Sindicato e Estado: suas relações na formação do proletariado de São Paulo. São Paulo: Ática, 1981, p. 151. (1a ed. São Paulo: Dominus/Edusp, 1966). Para uma análise mais detida sobre o assunto, cf. SILVA JUNIOR, Adhemar Lourenço da. As sociedades de socorros mútuos: estratégias privadas e públicas (estudo centrado no Rio Grande do Sul - Brasil, 1854-1940). Porto Alegre: 2004. Faculdade de Filosofia e Ciências Humanas da Pontifícia Universidade Católica do Rio Grande do Sul. (Tese de Doutorado), 2004.

${ }^{3}$ LUCA, Tânia Regina de. O sonho do futuro assegurado (o mutualismo em São Paulo). São Paulo/Brasília: Contexto/CNPq, 1990, p. 10.
} 
Bahia (165), Rio de Janeiro (144), Rio Grande do Sul (104) e Pernambuco (103). As demais unidades da Federação tiveram números inferiores a 100 entidades cada ${ }^{4}$.

A inexistência de uma legislação trabalhista e previdenciária e a necessidade de travar uma luta cotidiana contra o mal-estar social ligado ao desemprego, às doenças, aos acidentes de trabalho e à velhice ou à morte foram importantes fatores objetivos no processo de constituição, de expansão e de longevidade do mutualismo no Brasil. Tanto os súditos do Império (1822-1889) como os cidadãos da Primeira República (1889-1930) viviam, em sua maioria, em quase absoluto desamparo social e marginalidade política. A abolição da escravidão, em 13 de maio de 1888, não resultou na integração, à sociedade, das legiões de negros e de mestiços, que, em sua maioria, continuaram a viver de forma muito modesta ou miserável. A proclamação da república, em 15 de novembro de 1889, também não alterou de modo radical o quadro, anteriormente, traçado, pois sua Constituição (1891) adotou um liberalismo de matriz bastante estreita, que, combinado com a ascensão e o domínio das oligarquias e do coronelismo, condenou a classe trabalhadora e os pobres a uma total falta de proteção frente ao patronato e a sérias limitações, no que tange à possibilidade de influenciar nos processos decisórios acerca dos rumos políticos do país 5 .

A grande expectativa das classes subalternas com o novo regime logo se dissipou ou tendeu a se dissipar quando as mudanças sociais não vieram. As longas jornadas de trabalho, os abusos ligados à exploração da mão-de-obra infantil e feminina, a rígida disciplina, a falta de segurança e de higiene nas fábricas e nas manufaturas e os baixíssimos salários fizeram com que a classe trabalhadora e os outros grupos sociais subalternos usassem de sua inventividade para criar condições de sobrevivência frente ao mundo sombrio onde viviam. Para isso, recriaram e adaptaram experiências dos trabalhadores de outros países, visando a enfrentar, coletivamente, os dissabores da vida.

As sociedades de auxílio mútuo, portanto, funcionavam, sobretudo, como caixas de previdência para as quais os associados contribuíam mensalmente com uma quantia previamente estabelecida em seus estatutos. Um grande número delas exigia, também, uma taxa de adesão, de valor mais elevado, comumente chamada de joia. Os

\footnotetext{
${ }^{4}$ BRASIL. Anuário Estatístico do Brasil (1936). V. 2. Rio de Janeiro: IBGE, 1936.

${ }^{5}$ A despeito dos limites impostos pelo sistema político e eleitoral, uma fração importante da classe operária, formada pelos artífices, conseguiu atuar, com grande sucesso, nas eleições das três primeiras décadas republicanas, inclusive elegendo dezenas de operários de ofício para os cargos de conselheiro municipal (vereador) e de juiz de paz. Sobre o assunto, cf. CASTELLUCCI, Aldrin. Política e cidadania operária em Salvador (1890-1919). Revista de História (USP). São Paulo: [s.e.], no 162, pp. 205-241, 1o semestre de 2010.
} 
serviços prestados pelas sociedades mutualistas podiam ser bem amplos: desde uma remuneração para os dias parados nos momentos de doença, passando pela pensão por invalidez do associado ou, em caso de morte, para seus dependentes, assistência médica, farmacêutica e jurídica, além do auxílio funeral, herança das antigas irmandades religiosas.

O primado da necessidade, contudo, não era o único motivo para a associação. Havia, na realidade, um duplo condicionante no movimento que levava as pessoas a se agruparem. Em muitos casos, os fatores objetivos combinavam-se com os subjetivos, relacionados à construção de identidades. Nesse sentido, como sustentou Claudio Batalha, não há como dissociar o surgimento das primeiras sociedades de artesãos do processo de valorização dos ofícios qualificados e da visão positiva do trabalho como um elemento que distingue os trabalhadores dos pobres, que eram associados ao ócio e ao vício, e determinante na definição de uma identidade de classe operária, ligada ao trabalho regular e à organização ${ }^{6}$.

\section{MUTUALISMO E FORMAÇÃO DA CLASSE OPERÁRIA NA BAHIA}

$\mathrm{Na}$ Bahia, por meio de um mapeamento inicial, conseguimos identificar e obter informações diversas para 145 associações autodenominadas como de auxílio mútuo, beneficentes, filantrópicas e cooperativas, em Salvador e em várias cidades interioranas do estado, fundadas entre 1832 e 1930, período em que o fenômeno foi mais significativo. Elas foram criadas através da iniciativa dos trabalhadores, de seus patrões (caso típico das fábricas têxteis, de calçados, de cigarros e de charutos e das ferrovias), da Igreja Católica, de elementos de destaque das elites locais ou mesmo do Estado e de suas autoridades. Essas entidades congregavam operários de um ou mais ofícios, de uma empresa, de uma fábrica ou de uma oficina, de uma cidade ou de um bairro ou eram organizações étnico-nacionais - de negros e de imigrantes (espanhóis, portugueses, italianos, franceses, alemães e suíços). Nesse caso, não existia separação entre trabalhadores e patrões, ricos e pobres etc. Havia, ainda, as sociedades de ajuda mútua de funcionários públicos das esferas dos poderes executivo e judiciário, de profissionais liberais, de empregados do comércio e dos outros setores de serviços, de estudantes, de militares e de ex-combatentes. Como observou Cláudia Viscardi, essa

\footnotetext{
${ }^{6}$ BATALHA. Cláudio. Identidade da classe operária no Brasil (1880-1920): atipicidade ou legitimidade. Revista Brasileira de História. São Paulo: [s.e.], V. 12, nso. 23-24, p. 111-124, set./ago., 1992.
} 
nomenclatura dizia respeito a fenômenos diferentes e complexos que, muitas vezes, se confundiam ${ }^{7}$.

O ano de 1832, em Salvador, foi um marco no processo de constituição das primeiras associações de auxílio mútuo e de formação da classe operária na Bahia. No dia 16 de setembro daquele ano, depois de algumas reuniões preparatórias, um grupo de homens negros, liderados por Manoel Victor Serra, fundou a Irmandade de Nossa Senhora da Soledade Amparo dos Desvalidos. Suas disposições estatutárias estabeleciam que a entidade seria formada por um "número ilimitado de sócios brasileiros natos de cor preta". Portanto, originalmente, ela era uma irmandade religiosa composta, exclusivamente, por brasileiros negros. Em 23 de fevereiro de 1834, quando foram feitas as primeiras eleições para sua diretoria, a entidade já contava com algumas dezenas de associados. Naquele momento, funcionava nas dependências de outra sociedade religiosa, isto é, na capela da Irmandade de Nossa Senhora do Rosário dos Quinze Mistérios. Contudo, um conflito envolvendo os irmãos de ambas as associações fez com que a Irmandade dos Desvalidos fosse expulsa, em 1848, sendo abrigada pela Irmandade de Nossa Senhora das Portas do Carmo. Em 1851, os membros da irmandade fizeram uma reforma em seus estatutos e mudaram seu nome para Sociedade Protetora dos Desvalidos, mantendo-se, contudo, como uma entidade exclusiva de homens negros. Em 1868, a direção da Irmandade de Nossa Senhora das Portas do Carmo também entrou em conflito com os membros da Sociedade Protetora dos Desvalidos e pediu a desocupação de suas dependências. A partir de então, a Sociedade Protetora dos Desvalidos conseguiu se estabelecer, temporariamente, na rua do Bispo, depois, em sede própria, no Cruzeiro de São Francisco, Centro Histórico de Salvador ${ }^{8}$.

A segunda entidade que nos interessa é a Sociedade Montepio dos Artífices da Bahia, fundada, em Salvador, no dia 16 de dezembro de $1832^{9}$. Como seu próprio

\footnotetext{
${ }^{7}$ VISCARDI, Claudia Maria Ribeiro. Experiências da prática associativa no Brasil (1860-1880). Topoi. Juiz de Fora: [s.e.], V. 9, no. 16, pp. 117-136, jan./jun., 2008.

${ }^{8}$ DIÁRIO OFICIAL DO ESTADO DA BAHIA. Salvador: Imprensa Oficial do Estado da Bahia, pp. 494-496, 2 jul., 1923. Edição Especial do Centenário.; HISTÓRICO e Relatório da Sociedade Protetora dos Desvalidos 1832-1932. Apresentado pelo Presidente do Diretório Juventino Silvino da Costa. Aprovado em Assembléia Geral de 7 de setembro de 1934. Exercício de 1931-1934. Bahia, 1934.; ESTATUTOS da Sociedade Protetora dos Desvalidos. Instalada na Bahia em 16 de setembro de 1832. Aprovados em Assembléia Geral de 5 de junho de 1929. Bahia: Typographia Ideal, 1929.

${ }^{9} \mathrm{O}$ nome original dessa associação era Sociedade dos Artífices. Em 1842, ela passou a se chamar Imperial Sociedade dos Artífices, prova do reconhecimento da elite dirigente do país com relação à crescente influência e importância adquirida por ela junto aos artesãos. Em 1862, uma reforma de seus estatutos alterou seu nome, definitivamente, para Sociedade Montepio dos Artífices da Bahia. Sobre o assunto, cf. COSTA E SILVA, Maria da Conceição Barbosa da. O montepio dos artistas: elo dos trabalhadores em Salvador. Salvador: Secretaria da Cultura e Turismo do Estado da Bahia/Fundação Cultural/EGBA, 1998.
} 
nome sugere, nasceu como entidade laica e tinha, como critério associativo, os ofícios artesanais e não a nacionalidade, a cor, a etnia ou a religião, embora também possuísse um santo padroeiro (Nossa Senhora de Santana) e fosse proprietária de carneiros, no Cemitério da Quinta dos Lázaros, pertencente às irmandades católicas.

O movimento financeiro detalhado e constante do relatório, de 1853, leva-nos a crer no vigor e na boa penetração da Sociedade Montepio dos Artífices da Bahia junto aos trabalhadores de ofício. Naquele ano, a direção da entidade reportou aos associados uma receita de 5:237\$186 (cinco contos, duzentos e trinta e sete mil e cento e oitenta e seis réis), sendo que 2:338\$885 representavam o saldo em 1852, ao passo que $160 \$ 000$ correspondiam ao recebimento de joias referentes à entrada de novos sócios, $257 \$ 500$ provinham das mensalidades recebidas dos associados, $386 \$ 905$ eram originários do recebimento de prêmios de dinheiro emprestado a juros e $250 \$ 400$ foram recebidos devido ao penhor de uma casa. Multas e outros penhores completavam o total de receitas. As despesas totalizaram 4:638\$480 e também foram minuciosamente descritas. Elas diziam respeito a "socorros de viúvas e filhos de sócios que faleceram em pobreza" (290\$000), a “socorros a sócios doentes afastados do trabalho" (60\$500), a "sepultamento de sócios pobres" (29\$440), a impressão dos novos estatutos e diplomas (156\$000), a material para o expediente e a escrituração social (115\$100), a um grande volume de recursos "emprestados sobre firmas" (1:530\$000) e "emprestados sobre penhores" (2:313\$220), entre outros. Deduzidas as despesas das receitas, o valor líquido era de $598 \$ 706$ que, somados ao "valor das letras e penhores", formavam um capital de $4: 441 \$ 926^{10}$.

Esses dados sobre as formas de investimentos devem ser retidos, pois ajudarão no entendimento do conflito e da cisão ocorrida em 1853. Mas as fontes informamnos ainda que grande parte dos artesãos filiados à Sociedade Montepio dos Artífices trabalhava nos Arsenais de Marinha e de Guerra da Bahia. Ao finalizar seu relatório, Francisco Anastácio Santos Mangabeira dirigiu-se, da seguinte forma, aos seus companheiros, por ele qualificados como "artistas nacionais", isto é, brasileiros, majoritariamente negros e mestiços:

Aqui concluo este meu amesquinhado trabalho participando-vos por fim, que levado ao alto conhecimento do Exmo Sr. Presidente da Província a vossa representação solicitando a proteção do governo em favor da classe dos artistas nacionais, afim de serem com preferência admitidos ao trabalho dos Arsenais de Marinha e Guerra e das obras públicas, foi ela acolhida,

\footnotetext{
${ }^{10}$ Arquivo Público do Estado da Bahia (APEB). Seção de Arquivo Colonial e Provincial, Presidência da Província, maço no 1575, (1833-1889).
} 
como era de esperar de um governo patriótico, sábio, justo e perspicaz, amigo e pai do povo, e desejoso de seu bem e prosperidade. ${ }^{11}$

Ao longo da segunda metade do século XIX e nos primeiros anos do XX, o movimento associativo da Sociedade Montepio dos Artífices da Bahia não parece ter sofrido grande alteração, apesar das diferentes conjunturas e dificuldades enfrentadas pela associação. Em 1893, o número de filiados era de 132 e, em 1911, quando a entidade comemorava o seu 79ㅇ aniversário de fundação, o total de sócios era de 139, sendo 21 remidos e 108 efetivos $^{12}$. Todavia, na década de 1920, a Sociedade Montepio dos Artífices da Bahia parece ter tido um incremento em seu movimento associativo. Em 1926 e 1927, ela já tinha 188 sócios. Em 1929 e em 1930, esse número saltou para 381 e para 369 filiados, respectivamente ${ }^{13}$.

\section{TABELA 1:}

SOCIEDADES MUTUALISTAS DE OPERÁRIOS - BAHIA (1832-1930)

\begin{tabular}{|c|c|c|c|c|}
\hline Nome & Fundação & Reorganização & P. Notícia & Cidade \\
\hline Sociedade Protetora dos Desvalidos & 16/09/1832 & 05/06/1929 & & Salvador \\
\hline Sociedade Montepio dos Artífices da Bahia & $16 / 12 / 1832$ & & & Salvador \\
\hline Sociedade Montepio dos Artistas & $02 / 02 / 1853$ & & & Salvador \\
\hline Sociedade Humanitária dos Artistas & $13 / 06 / 1856$ & & & Salvador \\
\hline $\begin{array}{l}\text { Sociedade Protetora e Beneficente dos Artífices } \\
\text { Carpinteiros e Calafates }\end{array}$ & $03 / 03 / 1860$ & & & Salvador \\
\hline Sociedade Montepio dos Artistas Nazarenos & 08/09/1861 & & & Nazaré \\
\hline Associação Tipográfica Baiana & 16/04/1871 & ??/??/1904 & & Salvador \\
\hline $\begin{array}{l}\text { Sociedade Bolsa de Caridade do Arsenal de } \\
\text { Guerra da Bahia }\end{array}$ & 08/05/1872 & & & Salvador \\
\hline Sociedade Montepio dos Artistas Feirenses & 08/09/1876 & & & Feira de Santana \\
\hline Sociedade Beneficente União das Classes & $15 / 11 / 1895$ & & & Salvador \\
\hline $\begin{array}{l}\text { Sociedade Beneficente União Filantrópica dos } \\
\text { Artistas }\end{array}$ & 07/06/1889 & & & Salvador \\
\hline Clube Defensor e Beneficente dos Maquinistas & $11 / 10 / 1889$ & & & Salvador \\
\hline Sociedade Cooperativa dos Alfaiates & $01 / 01 / 1890$ & & & Salvador \\
\hline Sociedade Bolsa dos Chapeleiros & $12 / 09 / 1891$ & & & Salvador \\
\hline Sociedade Montepio dos Artistas Cachoeiranos & & & ??/??/1891 & Cachoeira \\
\hline Associação Protetora dos Homens do Mar & & & 05/07/1892 & Salvador \\
\hline Centro Operário da Bahia & 06/05/1894 & 09/07/1911 & & Salvador \\
\hline Sociedade Beneficência 1ㅇ de Maio & ??/05/1894 & & & Salvador \\
\hline Sociedade Montepio dos Artistas Amargosenses & $13 / 05 / 1895$ & & & Amargosa \\
\hline Sociedade Beneficente União das Classes & $15 / 11 / 1895$ & & & Salvador \\
\hline
\end{tabular}

\footnotetext{
${ }^{11}$ APEB, Seção de Arquivo Colonial e Provincial, Presidência da Província, maço 1575 (1833-1889).

${ }^{12}$ VIANNA, Francisco Vicente. Memória sobre o estado da Bahia. Salvador: Tipografia do Diário da Bahia, 1893, p. 393 e Diário de Notícias, Salvador, 18 fev. 1911, p. 2..

13 Relatório da Sociedade Montepio dos Artífices apresentado pelo presidente do Conselho Administrativo, José Felix Simões, referente ao exercício de 1926-1926. Aprovado em Sessão de Assembleia Geral de 9 de fevereiro de 1928. Bahia: Tipographia do Povo, 1928; Relatório do Conselho Administrativo da Sociedade Montepio dos Artífices no exercício de 1927 a 1929. Presidente Marcos Evangelista dos Santos. Bahia: Typ. da "Porta São Miguel", 1929; Relatório do Conselho Administrativo da Sociedade Montepio dos Artífices no exercício de 1929-1931. Presidente - Marcos Evangelista dos Santos. Apresentado em Assembleia Geral de 11 de dezembro de 1931 e na mesma aprovado. Typ. da "Porta São Miguel", 1932.
} 


\begin{tabular}{|c|c|c|c|c|}
\hline Sociedade Beneficente União dos Alfaiates & $01 / 04 / 1898$ & 03/06/1919 & & Salvador \\
\hline Sociedade Beneficente Cachoeirana & & & ??/??/1900 & Cachoeira \\
\hline Sociedade Montepio União Operária de São Félix & & & 04/06/1901 & São Félix \\
\hline Sociedade Montepio dos Artistas Iraraenses & 24/07/1903 & & & Irará \\
\hline Sociedade Beneficente dos Mares & & & ??/??/1903 & Salvador \\
\hline Sociedade Beneficente União das Artes & 01/05/1904 & & & S. A. de Jesus \\
\hline $\begin{array}{l}\text { Sociedade Cooperativa dos Operários } \\
\text { Canavieirenses }\end{array}$ & 09/05/1904 & & & Canavieiras \\
\hline Grêmio das Artes Gráficas & 24/02/1905 & & & Salvador \\
\hline Sociedade Beneficente União Auxiliadora & $22 / 04 / 1906$ & $26 / 03 / 1916$ & & Salvador \\
\hline $\begin{array}{l}\text { Clube Beneficente e Defensor dos Operários } \\
\text { Mecânicos }\end{array}$ & 01/11/1907 & & & Salvador \\
\hline $\begin{array}{l}\text { Sociedade Beneficente dos Empregados nas } \\
\text { Capatazias de Alfândega }\end{array}$ & $14 / 06 / 1908$ & & & Salvador \\
\hline Cooperativa dos Homens do Mar & 11/06/1909 & & & Salvador \\
\hline União Operária Beneficente de Caitité & & & $15 / 03 / 1912$ & Caitité \\
\hline Beneficência Operária 23 de Novembro & & & $12 / 11 / 1910$ & Salvador \\
\hline Sociedade Beneficente União dos Padeiros & 09/06/1912 & & & Salvador \\
\hline $\begin{array}{l}\text { Sociedade União Defensora e Beneficente dos } \\
\text { Pintores da Bahia }\end{array}$ & $26 / 02 / 1919$ & & & Salvador \\
\hline $\begin{array}{lllll}\text { Sociedade Beneficente e } & \text { Defensora dos } \\
\text { Eletricistas } & & & & \\
\end{array}$ & $20 / 07 / 1919$ & & & Salvador \\
\hline Beneficência Operária Sanfelixta & $17 / 08 / 1919$ & & & Salvador \\
\hline Sociedade Montepio dos Artistas de Itabuna & $12 / 09 / 1921$ & & & Itabuna \\
\hline $\begin{array}{l}\text { Sociedade Beneficente dos Artistas e Operários } \\
\text { da Cidade de llhéus }\end{array}$ & & & ??/??/1922 & Illhéus \\
\hline União Operária Beneficente & & & $12 / 09 / 1922$ & Salvador \\
\hline $\begin{array}{llll}\text { Sociedade Beneficente } & \text { dos } & \text { Artistas } \\
\text { Santoantonienses } & & & \end{array}$ & 09/09/1929 & & & S. A. de Jesus \\
\hline
\end{tabular}

Fontes: APEB, Documentos das Seções Colonial e Provincial; Legislativa; e Republicana; Jornais Diversos (18901922); Diário Oficial do E. da Bahia (1915-1923); Estatutos, Atas e Relatórios das Associações; Almanaques; Memórias.

Essas duas entidades condensam e expressam, de modo radical, as características fundamentais do processo de formação da classe operária na Bahia: origem étnico-nacional, fundamentalmente, brasileira e negro-mestiça e secular preeminência dos artesãos e dos mestres de ofícios em relação aos operários fabris. Esses dois traços fundamentais estiveram presentes, no longo período que se estende da primeira metade do século XIX até o final da Primeira República, em 1930, pois, como se sabe, não houve imigração estrangeira massiva para a Bahia e as dezenas de grandes fábricas que foram fundadas, no período, empregadoras de milhares de operários, conviveram com as centenas de pequenas oficinas e as obras públicas tocadas por pequenos empreiteiros, nas quais os artesãos continuaram a exercer seus ofícios por muito tempo. Na Bahia, o associativismo foi um fenômeno exclusivo dos artesãos, no período que vai da primeira metade do século XIX à primeira década do século XX. Foi apenas, nas décadas de 1910 e de 1920, que surgiram, com relativa 
força, as primeiras organizações sindicais dos operários do complexo portuário, dos setores de transportes urbanos, ferroviários, marítimos e fluviais e das fábricas ${ }^{14}$.

A Sociedade Montepio dos Artífices foi a pioneira dentre as muitas associações de artesãos que compunham o primeiro tipo de associativismo que estamos examinando, isto é, o dos trabalhadores manuais qualificados. A Tabela 1 indica que, a partir de 1832, dezenas de outras associações de artesãos foram criadas. Uma delas foi a Sociedade Montepio dos Artistas, fundada em Salvador no dia 2 de fevereiro de 1853, dia da festa de Nossa Senhora da Purificação. Mais uma evidência dos possíveis vínculos históricos existentes entre sociedades mutualistas, Sociedade Montepio dos Artistas foi criada através de uma dissidência da Sociedade Montepio dos Artífices, aparentemente em função de divergências surgidas, em março de 1852, sobre a melhor maneira de aplicar os recursos da entidade. O sócio fundador João Isidoro Pereira teria insinuado que a transferência das reservas monetárias do antigo sistema de penhores para a Caixa de Comércio da Bahia atenderia a interesses ilegítimos. Em agosto de 1852, a crise se aprofundou com o pedido de desligamento coletivo de dezesseis sócios. Nos dias que se seguiram, os dois grupos entraram em conflito, culminando com a expulsão dos dissidentes. Eles, por sua vez, uniram-se a outros três indivíduos e fundaram a Sociedade Montepio dos Artistas. O fato é que a entidade criada pelo grupo dos dezenove teve (e continuou a ter, por muito tempo) a mesma base social da instituição da qual nasceu: os artífices. Dentre eles, havia um grande número de alfaiates, carapinas, carpinteiros, marceneiros, sapateiros, tipógrafos, entre outros. Esses artesãos foram classificados em termos étnico-raciais pelas fontes consultadas pela autora como brancos, pardos, pretos, mestiços, cabras e crioulos, havendo evidências de que muitos deles eram ex-escravos ou descendentes de escravos. Apesar do decréscimo posterior, a Sociedade Montepio dos Artistas parece ter atraído um grande número de trabalhadores qualificados, em seus primórdios. De 1852 a 1862, chegou a receber 592 associados $^{15}$.

Além de terem tomado parte ativa na Sociedade Montepio dos Artífices, os operários dos Arsenais de Guerra e da Marinha criaram outras duas associações de socorro mútuos. Uma delas foi a Sociedade Humanitária dos Artistas, fundada em 13 de junho de 1856, que teve como protagonistas os calafates e os carpinteiros do Arsenal de Marinha da Bahia. Em 1884, foi feita uma reforma nos estatutos da Sociedade Humanitária dos Artistas, abrindo-a para a filiação de artesãos de outros

\footnotetext{
${ }^{14}$ Sobre esse assunto, cf. CASTELLUCCI, Aldrin A. S. Industriais e operários baianos numa conjuntura de crise (1914-1921). Salvador: Fieb, 2004 (II Prêmio Fieb de Economia Industrial); Idem. Flutuações econômicas, crise política e greve geral na Bahia da Primeira República. Revista Brasileira de História. São Paulo: [s.e.], V. 25, no. 50, pp. 131-166, [s.m.], 2005.

${ }^{15}$ COSTA E SILVA, Maria da Conceição Barbosa da. O montepio... op. cit.
} 
ofícios, inclusive aos trabalhadores que não pertenciam ao Arsenal de Marinha. Em 1890, possuía 208 sócios, dos quais apenas 132 estavam em dia com suas contribuições. No início de 1906, o número de sócios efetivos havia caído para 50. Provavelmente, essas dificuldades deviam-se ao fato de que o Arsenal de Marinha da Bahia ter sido fechado, em 5 de janeiro de 1899, extinguindo os postos de trabalho de centenas de operários e solapando parte significativa da base social de sustentação da associação, em uma época já marcada por uma profunda crise econômica e financeira que afetava todo o país, caracterizada pelo fechamento de fábricas, pela paralisação de obras e por muito desemprego ${ }^{16}$.

A outra associação foi iniciativa dos operários do Arsenal de Guerra. Ela foi fundada, no dia 8 de maio de 1872, e era denominada, originalmente, Sociedade Bolsa de Caridade do Arsenal de Guerra da Bahia. A organização contou com a liderança de Justino Pereira de Britto, mestre da oficina de latoeiros e funileiros e alferes honorário do Exército. Seguindo a tradição de eleger um santo padroeiro, a entidade foi posta sob a proteção de Nossa Senhora do Noviciado, sendo, oficialmente, instalada na igreja dos Órfãos de São Joaquim. Era, pois, uma associação mutualista fechada, que congregava, exclusivamente, os operários do Arsenal de Guerra. Com a crise e a posterior extinção dos Arsenais, seus estatutos foram reformados e passou a se chamar, simplesmente, Sociedade Bolsa de Caridade, transformando-se em uma sociedade mutualista aberta, admitindo em seus quadros "artistas e profissionais em geral". Além disso, foi permitida a "admissão de senhoras parentas dos sócios". Posteriormente, além das esposas, os filhos dos sócios também puderam filiar-se, sendo dado a ambos o direito de votar e ser votado para qualquer cargo ${ }^{17}$.

A estratégia adotada pela Sociedade Bolsa de Caridade parece ter sido eficaz, pelo menos, em termos de securitização. Após a reforma de seus estatutos, o número de associados aumentou consideravelmente, possibilitando, inclusive, a ampliação e a melhoria quantitativa e qualitativa dos socorros oferecidos a seus membros. Em 1892, trinta anos após sua fundação, a Bolsa de Caridade possuía 365 sócios. De 1905 até 1917, os relatórios registraram números superiores a mil associados, subindo para uma média acima de 1.200 membros, entre 1920 e 1923. Devemos levar em consideração a queixa registrada pela diretoria, na assembleia de prestação de contas, realizada no dia 21 de julho de 1907, de acordo com a qual, dos 1.053 associados existentes naquele ano, apenas 350 estavam pagando suas mensalidades pontualmente. O problema, aliás, vinha de antes, já que, de 1901 a 1906, dos mais de

\footnotetext{
${ }^{16}$ Jornal de Notícias, Salvador, 28 abr. 1890, p. 1.; Ibidem, 11 abr. 1906, p. 2.

${ }^{17}$ DIÁRIO OFICIAL DO ESTADO DA BAHIA. Salvador: Imprensa Oficial do Estado da Bahia, pp. 494-496, 2 jul. 1923. Edição Especial do Centenário.
} 
mil filiados, apenas 500 estavam pagando suas contribuições regularmente. Ainda assim, esses são números expressivos, em termos de arrecadação de fundos, aos quais devem ser acrescidas as receitas derivadas das subvenções estatais e os rendimentos oriundos das operações financeiras da entidade ${ }^{18}$.

No final do Império, ainda foi fundada mais uma importante associação congregando artesãos de diversos ofícios. Trata-se da Sociedade União Philantropica dos Artistas, instituída, em 7 de junho de 1889, tendo São Pedro como padroeiro. Em 1893, apenas quatro anos depois de criada, ela já possuía 645 sócios, número que subiu para 789, em 1894. Nesse ano, a União Philantropica dos Artistas socorreu 21 sócios enfermos e custeou os funerais de outros nove, gozando de boa saúde financeira, já que sua receita havia sido de 13:242\$814 e sua despesa de apenas 3:980\$635, restando-lhe um saldo de 9:262\$179 ${ }^{19}$.

A partir da segunda metade do século XIX, além das associações de auxílio mútuo que agrupavam diversas profissões, foi possível localizarmos também várias

\footnotetext{
${ }^{18}$ RELATÓRIO apresentado à Assembléia Geral da Sociedade Bolsa de Caridade pelo Presidente da Direção Eduardo Victoriano de Souza na Sessão Magna do 21ㅇan aniversário em 11 de maio de 1893. Bahia: Litho-Typographia V. de Oliveira \& C., 1893.; RELATÓRIO apresentado à Assembléia Geral da Sociedade Bolsa de Caridade pelo Presidente da Direção Eduardo Victoriano de Souza na Sessão Magna do 22 을 aniversário em 27 de maio de 1894. Bahia: Litho-Typographia V. de Oliveira \& C., 1894.; RELATÓRIO apresentado em Assembléia Geral da Sociedade Bolsa de Caridade pelo Presidente do Diretório Euthymio da Cruz Baptista em Sessão Magna comemorativa do 31 aniversário em 14 de julho de 1903. Bahia, 1903.; RELATÓRIO apresentado em Assembléia Geral da Sociedade Bolsa de Caridade pelo Presidente do Diretório Euthymio da Cruz Baptista em Sessão Magna comemorativa do 35o aniversário em 14 de julho de 1907. Bahia, 1907.; RELATÓRIO Sociedade Bolsa de Caridade exercício de 1907 a 1908. Presidente do Diretório Capitão Euthymio da Cruz Baptista em Sessão Magna comemorativa do 360 aniversário em 9 de agosto de 1908. Bahia, 1908.; RELATÓRIO apresentado em Assembléia Geral da Sociedade Bolsa de Caridade pelo Presidente do Conselho Diretório J. Prudencio F. de Carvalho em Sessão Magna comemorativa do 40 aniversário em 30 de junho de 1912. Bahia: Typographia e Encadernação do Liceu de Artes e Ofícios, 1912.; RELATÓRIO apresentado em Assembléia Geral da Sociedade Bolsa de Caridade pelo presidente do conselho diretório J. Prudencio F. de Carvalho em Sessão Magna comemorativa do 410 aniversário em 13 de julho de 1913. Bahia: Typographia e Encadernação do Liceu de Artes e Ofícios, 1913.; RELATÓRIO apresentado em Assembléia Geral da Sociedade Bolsa de Caridade pelo Presidente do Conselho Diretório J. Prudencio F. de Carvalho em Sessão Magna comemorativa do 42ㅇ aniversário em 13 de setembro de 1914. Bahia: Typographia e Encadernação do Liceu de Artes e Ofícios, 1914.; RELATÓRIO apresentado em Assembléia Geral da Sociedade Bolsa de Caridade pelo Presidente do Conselho Diretório José Prudencio F. de Carvalho na Assembléia Geral realizada em 7 de julho de 1916 e unanimemente aprovado. Bahia: Typographia e Encadernação do Liceu de Artes e Ofícios, 1916.; RELATÓRIO apresentado em Assembléia Geral da Sociedade Bolsa de Caridade pelo Presidente do Conselho Diretório José Prudencio F. de Carvalho na Sessão realizada em 27 de junho de 1918 e unanimemente aprovado. Bahia: Typographia e Encadernação do Liceu de Artes e Ofícios, 1918. e RELATÓRIO da Sociedade Bolsa de Caridade Cinqüenta anos de existência. 1872-1922. O seu movimento no exercício de 1921 a 1922, relatado pelo Presidente do Diretório J. Prudencio F. de Carvalho, em Assembléia Geral de 20 de junho de 1922 e na mesma, unanimemente, aprovado. Bahia: Typographia e Encadernação do Liceu de Artes e Ofícios, 1922.

${ }^{19}$ RELATÓRIO da Direção da Sociedade Philantropica dos Artistas. Exercício de 1894 a 1895. Apresentado em Assembléia Geral de 2 de junho de 1895. Bahia: Imprensa Moderna, 1895. In: APEB, Seção Legislativa, Câmara dos Deputados, Ofícios Recebidos e Expedidos (1895-1896), livro 1189.
} 
organizações que reuniam apenas os artífices de um ofício ou de ofícios correlatos. Um exemplo é a Sociedade Protetora e Beneficente dos Artífices Carpinteiros e Calafates, fundada em Salvador no dia 3 de março de 1860. Suas lideranças chegaram a redigir uma proposta de estatutos e encaminhá-la às autoridades imperiais, solicitando aprovação e autorização de funcionamento, conforme prescrevia a legislação da época. Contudo, não conseguimos obter informações mais substanciais sobre essa entidade ${ }^{20}$.

Bem diferente é o caso da Associação Typográphica Bahiana (ATB), fundada sob a proteção de Nossa Senhora da Piedade, em 30 de outubro de 1870, por 68 oficiais tipógrafos, encadernadores e litógrafos, sobre a qual abundam fontes e inexistem estudos históricos específicos. O tipógrafo e capitão honorário do Exército, João Capistrano Fernandes, foi seu presidente provisório. Em 25 de fevereiro de 1871, foram aprovados seus estatutos e, em 16 de abril do mesmo ano, foi realizada a instalação solene da Associação no Paço da Câmara Municipal de Salvador, sendo empossado José Firmino Cavalcante como presidente efetivo da Typográphica, por meio de nomeação do governo da província, de acordo com o que prescrevia o decreto imperial 2.711, de 19 de dezembro de $1860^{21}$. O movimento associativo da Associação Typográphica foi, relativamente, estável ao longo do século XIX, tendo um contínuo e consistente aumento no número de filiados no século XX. Assim, em 1870, eram 68 membros, subindo para apenas 70 em 1893. Em 1904, eram 101 integrantes, número que aumentou para 148 em 1910, para 194 em 1915, para 241 em 1924 e atingiu o pico de 357 em $1922^{22}$.

\footnotetext{
${ }^{20}$ APEB, doc. cit., fls.

${ }^{21}$ DIÁRIO OFICIAL DO ESTADO DA BAHIA. Salvador: Imprensa Oficial do Estado da Bahia, p. 397,2 jul. 1923. Edição Especial do Centenário.

${ }^{22}$ RELATÓRIO apresentado à Assembléia Geral da Associação Typográphica Bahiana pelo Conselho Diretório de 1904 a 1905, em sessão de 30 de abril de 1905 e na mesma aprovado. Bahia: Imprensa Moderna, 1905.; RELATÓRIO apresentado à Assembléia Geral da Associação Typográphica Bahiana pelo Conselho Diretório de 1905 a 1906, em sessão de 22 de abril de 1906 e na mesma aprovado. Bahia: Tipografia e Encadernação do Liceu de Artes e Ofícios, 1906.; RELATÓRIO apresentado à Assembléia Geral da Associação Typográphica Bahiana pelo Conselho Diretório de 1906 a 1907, em sessão de Assembléia Geral de 21 de abril de 1907 e unanimemente aprovado. Bahia: Tipografia e Encadernação do Liceu de Artes e Ofícios, 1907.; RELATÓRIO apresentado à Assembléia Geral da Associação Typográphica Bahiana pelo Conselho Diretório de 1907 a 1908, em Assembléia Geral de 19 de abril de 1908 e unanimemente aprovado. Bahia: Tipografia e Encadernação do Liceu de Artes e Ofícios, 1908.; ASSOCIAÇÃO Typográphica Bahiana. Relatório apresentado pelo Conselho Diretório em sessão da Assembléia Geral de 25 de abril de 1909, exercício de 1908 a 1909. Bahia: Tipografia e Encadernação do Liceu de Artes e Ofícios, 1909.; ASSOCIAÇÃO Typográphica Bahiana. Relatório do exercício de 1909 a 1910, apresentado pelo Conselho Diretório em sessão da Assembléia Geral de 24 de abril de 1910. Bahia: Tipografia e Encadernação do Liceu de Artes e Ofícios, 1910.; ASSOCIAÇÃO Typográphica Bahiana. Relatório do exercício de 1910 a 1911, apresentado pelo Conselho Diretório em sessão da Assembléia Geral de 16 de abril de 1911. Bahia: Tipografia e Encadernação do Liceu de Artes e Ofícios, 1911.; ASSOCIAÇÃO Typográphica Bahiana. Relatório apresentado pelo Conselho Diretório em Assembléia
} 
Além de escolas, a Associação Typográphica Bahiana mantinha uma biblioteca que foi criada, em 1883, com poucas publicações de livros, anais e teses da Faculdade de Medicina da Bahia, mas que, em 1910, já contava com 1.200 volumes, número que subiu para significativos 4.000 em 1923. Os relatórios anuais da entidade listavam as obras disponíveis e o número de consultas que cada uma delas recebeu dos associados, em cada período. Esses dados, somados aos contidos na Revista da Associação Typográphica Bahiana, publicada entre julho de 1902 e outubro de 1903, dizem-nos algo sobre o que os trabalhadores baianos liam entre a segunda metade do século XIX e as primeiras décadas do XX, um tema que merece um estudo à parte ${ }^{23}$.

Outro aspecto que deve ser destacado é o envolvimento que a Associação Typográphica Bahiana teve com a "greve geral" dos tipógrafos de Salvador, em abril de 1891, apesar de as informações sobre esse movimento serem muito escassas e indiretas. A já citada memória de 1923 sobre a entidade diz que ela "patrocinou" o movimento paredista. Mas, não há menção a ele no amplo mapeamento feito por José Raimundo Fontes sobre o movimento grevista, na Bahia, no período de 1888 a $1930^{24}$. Ao que tudo indica, a grande imprensa, principal atingida pelo movimento, não noticiou os acontecimentos, nem mesmo, posteriormente. Contudo, o tipógrafo José Prudencio Ferreira de Carvalho, dirigente da entidade e partícipe dos eventos daquele tempo, no trabalho intitulado "Associação Typográphica Bahiana - Escorço de uma notícia histórica", publicado na Revista da ATB, de abril de 1903, traz-nos alguns elementos sobre o episódio. De acordo com sua versão, no dia 13 de abril de 1891, foi feita uma assembleia dos "artistas tipógrafos", na qual foram apresentadas e aprovadas as "bases da greve", ou seja, sua pauta de reivindicação. As "Bases para regular o trabalho tipográfico no estado da Bahia" criavam uma organização chamada

Geral de 28 de abril de 1912 e na mesma unanimemente aprovado, exercício de 1911 a 1912. Bahia: Tipografia e Encadernação do Liceu de Artes e Ofícios, 1912.; ASSOCIAÇÃO Typográphica Bahiana. Relatório do exercício de 1915 a 1916. Apresentado pelo Conselho Diretório em sessão da Assembléia Geral de 22 de junho de 1916. Bahia: Tipografia e Encadernação do Liceu de Artes e Ofícios, 1916.; RELATÓRIO do exercício de 1924 da Associação Typográphica Bahiana, apresentado pelo presidente do Conselho Diretório, Theodomiro Baptista, aprovado em sessão de Assembléia Geral do dia 8 de fevereiro de 1925. Bahia: Tipografia América, 1925. e ASSOCIAÇÃO Typográphica Bahiana. Relatório do exercício de 1928, apresentado pelo Conselho Diretório, Caetano de Carvalho, aprovado em Assembléia Geral do dia 24 de fevereiro de 1929. Bahia: [s.e.], 1929.

${ }^{23}$ DIÁRIO OFICIAL DO ESTADO DA BAHIA. Salvador: Imprensa Oficial do Estado da Bahia, p. 397,2 jul. 1923. Edição Especial do Centenário.

24 FONTES, José Raimundo. Manifestações operárias na Bahia: o movimento grevista, 1888-1930. Salvador: Faculdade de Filosofia e Ciências Humanas da Universidade Federal da Bahia, Salvador. (Dissertação de Mestrado em Ciências Sociais), 1982. 
Fraternização Tipográfica e estabeleciam quais deveriam ser as atribuições e as remunerações dos ofícios tipográficos ${ }^{25}$.

Outro artesão participante da greve de abril de 1891 e da direção da Fraternização Tipográfica foi o tipógrafo Argemiro de Leão, que também era líder da União Operária Bahiana, a dissidência do Partido Operário da Bahia, fundado em 1890. Em março de 1891, ele chegou a publicar, ao menos, dois artigos assinados, refletindo sobre os objetivos das greves, no Pequeno Jornal, dirigido pelo médico liberal e abolicionista (depois, florianista) Aristides Cesar Spinola Zama (1837-1906). No primeiro, de 20 de março de 1891, sustentou que "a greve é o melhor meio empregado, quando as classes trabalhadoras sofrem, para conseguir uma melhoria" e que "o operário que contrariar este princípio é indigno do trabalho honrado". Justificou sua opinião com base no pressuposto de que "ninguém se atreverá a negar que o operário é o que mais trabalha e é o que menos é recompensado". Dessa ideia decorria a seguinte assertiva: “Desgraçado será o operário que não se unir aos outros! Pior será aquele que substituir ao que na defesa do seu direito for dispensado pelo patrão!". O tipógrafo Argemiro de Leão negou a existência de rivalidades, no interior da classe operária, e afirmou que os trabalhadores deveriam garantir, unidos, seus direitos, por meio da greve. Apelou aos seus "irmãos" para que, "por amor da pátria, da família e por dignidade do trabalho", virassem as costas aos patrões que não quisessem "pagar com justiça o trabalho recebido do operário" e que realizassem demissões dos que reivindicavam melhores salários ${ }^{26}$.

Em suas palavras finais, Argemiro de Leão condenou a prática da violência, declarou estar seguro de que tais métodos não existiam entre os trabalhadores da Bahia e apelou para que a classe operária mantivesse uma postura firme e persistente, quando ocorresse a deflagração de uma greve: "O operário que se levantar para pedir aumento de salário ao patrão tem o dever de não recuar". Assim procedendo, sua família o veria como uma pessoa dotada de "altivez". Mas, "transigir" com o patrão implicaria a continuidade da "fome" e a "desonra como aumento". Argemiro de Leão insistiu que escrevia em um momento oportuno para a deflagração de greves, e assegurou aos operários que eles não precisavam ter receios em relação ao governo, pois "ele é republicano e a república só visa o bem da humanidade". Em sua conclamação, o líder da dissidência propôs que as novas greves a serem deflagradas funcionassem como "vésperas" da "greve universal", que seria desencadeada no dia 1o

\footnotetext{
${ }^{25}$ CARVALHO, José Prudencio Ferreira de. Associação Typográphica Bahiana - Escorço de uma notícia histórica. Revista da Associação Typográphica Bahiana. Salvador: [s.e.], ano I, no 10, abril, 1903.

${ }^{26}$ LEÃO, Argemiro de. "Aos Operários". Pequeno Jornal. Salvador, 20 mar. 1891, p. 2
} 
de maio ${ }^{27}$. Esse é um primeiro indício de que algumas lideranças mais politizadas e escolarizadas já haviam tido contato com uma das ideias e das práticas mais marcantes da Segunda Internacional, apenas um ano após a sua adoção.

No segundo artigo, datado de 24 de março de 1891, Argemiro de Leão declarou que as greves daquele período estavam tomando "proporções gigantescas" e que ninguém se arriscaria a atentar contra elas, uma vez que, fazer isso seria um ato de "desumanidade", sujeito à punição pelos que "sofrem". Em sua segunda conclamação "aos operários", o "chefe da comissão de propaganda" da dissidência do Partido Operário disse que "se o capital deve ser garantido, o trabalho deve ser bem recompensado" e que "ordinariamente, o patrão enriquece pelo trabalho do operário". Portanto, a greve tinha por finalidade "evitar a fome da família do operário e obrigar o patrão a ter consciência". Mas, em sintonia com a referência anterior ao 1으 de maio, o tipógrafo Argemiro de Leão chamou a atenção de seus companheiros para o fato de que, se a reivindicação de aumento salarial era importante, cabia, no entanto, não deixar de pautar a necessidade de se "limitar as horas de trabalho" e "largar o trabalho nos sábados mais cedo do que nos outros dias da semana". Isto porque o operário precisava "receber a féria ainda a tempo de encontrar o comércio aberto para ele poder suprir a casa dos gêneros necessários à subsistência da família". O primeiro ponto estava bem próximo da reivindicação de jornada de trabalho de oito horas diárias, defendida pela Segunda Internacional como parte de suas atividades a partir do 1 o de maio de 1890, ao passo que a outra bandeira estava relacionada à chamada "semana inglesa", que, de acordo com o "chefe" da comissão de propaganda da União Operária Bahiana, já era assegurada aos operários do Arsenal de Marinha da Bahia $^{28}$.

Não sabemos se os tipógrafos foram bem-sucedidos em seu protesto. De todo modo, o que esse episódio diz-nos de mais importante é que algumas sociedades de auxílio mútuo podiam assumir funções próprias das associações de resistência, isto é, dos sindicatos. Como observou Claudio Batalha:

[...] a idéia de que as novas sociedades de resistência substituíram definitivamente as velhas sociedades mutualistas é falsa. O processo foi lento e bastante complexo. As sociedades mutualistas puras nunca desapareceram inteiramente. Por outro lado, algumas das velhas sociedades acabaram incorporando funções de resistência, do mesmo modo que algumas das novas sociedades de resistência adotaram práticas assistenciais. De fato, mesmo sem ter sido tão radical quanto se costuma

\footnotetext{
${ }^{27}$ Ibidem, p. 2.

${ }^{28}$ Idem. “Aos Operários". Pequeno Jornal. Salvador, 24 mar. 1891, p. 2.
} 
supor, certamente houve uma mudança visível nas formas de organização operária no início do século XX. ${ }^{29}$

No final do Império e nos primeiros anos da República, outras associações de auxílio mútuo, aglutinadoras de artesãos de um mesmo ofício ou de ofícios correlatos, foram fundadas. O primeiro exemplo merecedor de destaque é o do Club Defensor e Beneficente dos Maquinistas. Ele foi fundado em 1 o de outubro de 1889, mas seus estatutos só foram aprovados na assembleia geral dos associados, no dia 8 de setembro de 1897. Nele, encontramos, como primeiro artigo, a declaração de que a entidade seria composta por um "número ilimitado de sócios, maquinistas de qualquer nacionalidade, residentes no estado ou fora dele". O artigo segundo listava os fins da associação, incluindo defender os "interesses da classe", "socorrer os sócios em caso de moléstia, invalidez e prisão", custear o funeral dos sócios que falecessem e garantir uma pensão às suas famílias, auxiliar os filiados desempregados que empreendessem viagens para achar ocupação e criar uma biblioteca e um periódico, ambos voltados para o ofício de maquinista ${ }^{30}$.

O segundo caso é o da Sociedade Beneficente Bolsa dos Chapeleiros, instalada em 9 de agosto de $1891^{31}$. Não conseguimos localizar os estatutos da entidade, mas um relatório referente ao ano de 1897 revela que ela era aberta a trabalhadores dos dois sexos e parecia bem enraizada junto aos chapeleiros, dado que, naquele ano, ela possuía 260 sócios e 56 sócias. $^{32}$ Mas, há evidências de que a Bolsa dos Chapeleiros perdeu muitos filiados, na virada do século XIX para o XX, pois um relatório da associação informava que, em 1902, ela possuía 165 sócios, metade do que tinha cinco anos antes ${ }^{33}$. Isso estaria mais relacionado à crise econômica do setor do que a uma mudança no hábito de usar chapéus, como atesta a iconografia do período. $O$ terceiro exemplo é o da Sociedade União Beneficente dos Alfaiates, instalada, solenemente,

\footnotetext{
${ }^{29}$ BATALHA, Claudio H. M. Sociedades de trabalhadores no Rio de Janeiro no século XIX: algumas reflexões em torno da formação da classe operária. Cadernos AEL. [s.c.]: [s.e.], V. 6, nso 10-11, pp. 41-66, [s.m.], 1999. Outro exemplo de sociedade operária do século XIX que ultrapassou suas funções tradicionais de auxílio mútuo foi a Associação Tipográfica Fluminense, fundada na Corte do Rio de Janeiro, em 25/12/1853. Essa sociedade envolveu-se, desde o início, em atividades culturais, intervindo em problemas técnicos e econômicos do setor gráfico, exaltando a dignidade moral e o orgulho pelo ofício, tomando parte na organização de uma greve em 08/01/1858 e defendendo um abolicionismo lento, gradual e com indenização aos proprietários. VITORINO Artur José Renda. Máquinas e operários: mudança técnica e sindicalismo gráfico (São Paulo e Rio de Janeiro, 1858-1912). São Paulo: Annablume/Fapesp, 2000, pp. 69-119.

${ }^{30}$ ESTATUTOS do Club Defensor e Beneficente dos Maquinistas. Aprovados em Sessão da Assembléia Geral de 8 de setembro de 1897. In: Diário da Bahia, Salvador, 3 jan. 1903, pp. 2 -3.

${ }^{31}$ Diário da Bahia, Salvador, 12 ago. 1891, p. 1.

32 RELATÓRIO da Sociedade Beneficente Bolsa dos Chapeleiros apresentado à Assembléia Geral por João Victor Gonçalves, Presidente do Diretório. Bahia: Imprensa Moderna de Prudencio de Carvalho, 1898.

33 Jornal de Notícias, Salvador, 16 fev. 1903, p. 1.
} 
em 25 de março de 1897, e que tinha Nossa Senhora da Fé como padroeira. No início de 1903, ela já tinha 175 oficiais em seu quadro de associados ${ }^{34}$.

O caso do Centro Operário da Bahia era bem mais complexo, dado que não era uma organização que praticasse, exclusivamente, o auxílio mútuo. Suas origens remontam a junho de 1890, quando foi fundado o Partido Operário da Bahia, criado explicitamente para tomar parte das eleições para o congresso constituinte daquele ano. Em julho de 1890, o Partido Operário sofreu uma cisão que deu origem à União Operária Bahiana. Em junho de 1893, as lideranças operárias dessas duas organizações chegaram a um precário acordo que resultou na fundação do Centro Operário da Bahia, entidade que congregava cerca de cinco mil artesãos, grande parte deles egressos das duas entidades anteriores. A Constituição do Centro Operário do estado da Bahia, promulgada em 6 de maio de 1894, consagrava uma estrutura organizativa interna muito semelhante às adotadas pelo Partido Operário da Bahia e pela União Operária Bahiana, sendo, pois, quase um decalque dos elementos constitutivos das regras do sistema político surgido com a República, especialmente no que tange às eleições. Com efeito, a Constituição do Centro Operário da Bahia apresentava a instituição como um ente que falaria "em nome da união, prosperidade e garantias dos seus membros", assegurando o "desenvolvimento das artes, ofícios e indústrias" e aglutinando as "classes artística, operária e proletária". Do mesmo modo que ocorrera nas duas entidades que o antecederam, o Centro Operário da Bahia possuía um núcleo do qual se irradiavam as principais decisões. Esse centro político decisório era chamado de conselho executivo e era composto de 21 membros, inclusive, de um presidente, de um vice-presidente e de 1 o e 20 secretários. Em cada paróquia dos municípios, inclusive, na capital, haveria conselhos paroquiais do Centro Operário. As paróquias que tivessem dois distritos teriam o mesmo número de conselhos paroquiais. Os conselhos paroquiais teriam nove membros, inclusive, um presidente, um vice-presidente e 1 ㅇ e 20 secretários. Em cada vila, cidade ou comarca do interior do estado que tivesse um grupo de operários dispostos a aderir à entidade, seria organizado um conselho filial do Centro Operário. A direção dos conselhos filiais teria quinze membros e a mesma estrutura do conselho central e dos conselhos paroquiais. Os conselhos paroquiais só seriam formados quando possuíssem cem operários agremiados ou mais por paróquia, ao passo que era exigido um mínimo de cinquenta trabalhadores filiados para que fosse fundado um conselho filial.

Todos os cargos seriam eletivos, com mandatos de quatro anos, a contar da data da posse, que deveria ser feita trinta dias após a eleição, a ser marcada com, pelo

${ }^{34}$ Ibidem, 23 mar. 1897, p. 1 e ibidem, 26 mar. 1903, p. 2. 
menos, quinze dias de antecedência. Só poderiam votar os operários filiados e que estivessem quites com suas mensalidades. O sufrágio seria feito por uma chapa constando os nomes de todos os candidatos e seus respectivos cargos, do mesmo modo que ocorria nas eleições institucionais, só podendo "ser eleito e ocupar qualquer cargo do Centro Operário o agremiado associado que viver da profissão e estiver em dia com seus compromissos". Os "poderes" dos "novos eleitos" precisavam ser "reconhecidos" pelos que tivessem terminado seus mandatos, uma incrível semelhança com o esquema vigente na Primeira República, por meio do qual, a Câmara dos Deputados controlava sua própria renovação através da "comissão de verificação de poderes", promotora das famosas "degolas".

As mesmas disposições estatutárias do Centro Operário definiam, entre as muitas atribuições do conselho executivo, organizar um tribunal de arbitragem, composto de nove membros, com a finalidade de dirimir conflitos entre operários e proprietários, uma clara influência do pensamento do tipógrafo Luiz da França e Silva. A direção deveria organizar, também, uma tabela de preços de obras, com especificações quanto à idade e ao sexo do operário, bem como quanto à duração do trabalho. Os valores deveriam estar em sintonia com a variação do câmbio e dos preços dos gêneros de primeira necessidade. Este último ponto é um traço típico de sindicatos de ofício com pretensões de regulamentar, de proteger e até de controlar o mercado de trabalho em benefício de seus filiados, por meio do chamado closed shop, e, como vimos, já estava presente na Lei Orgânica do Partido Operário.

De acordo com sua constituição, o Centro Operário deveria lutar pela jornada de trabalho de oito horas, começando às oito da manhã e terminando às dezesseis horas, sem redução dos salários e combater o emprego de menores de dez anos e de mulheres casadas ou viúvas de sócios em "trabalhos forçados por necessidade". Essas bandeiras tinham sido, igualmente, defendidas pelos integrantes do Partido Operário da Bahia e da União Operária Bahiana, indicando a assunção, por parte dessas organizações, de funções que seriam assimiladas, posteriormente, pelos sindicatos.

A Constituição do Centro Operário estabelecia, ainda, que essa organização deveria oferecer cursos "primário", "secundário", "acessório" e "técnico", um ponto que, certamente, era tributário das preocupações que aqueles militantes sociais manifestaram, desde 1890, com a instrução como mecanismo de aquisição da cidadania política. Contudo, em sintonia com o que observou Claudio Batalha, em sua pesquisa sobre o Rio de Janeiro, os investimentos em educação de seus sócios parecia ser também um meio de garantir qualificação profissional aos filiados, com vistas ao 
controle do mercado de trabalho, nos moldes do que era feito pelas corporações de ofício, antes de serem proibidas pela Constituição Imperial de $1824^{35}$.

O Centro deveria criar, também, uma biblioteca, uma filarmônica e uma orquestra. Estabeleceria uma tipografia para uso dos oficiais sócios e para a impressão do jornal $A$ Voz do Operário, criaria uma casa de recolhimento de menores pobres e de órfãos de operários para que fossem treinados como aprendizes de um ofício e fundaria uma segunda casa de recolhimento destinada a abrigar os operários filiados vítimas de invalidez, velhice ou doença. O Centro também deveria instituir uma caixa de socorros para operários acometidos de moléstia ou invalidez, para auxílio funerário e pensão para viúvas em casos de morte ${ }^{36}$; fornecer assistência jurídica, nos litígios envolvendo operários, na condição de inocentes ou de perseguidos; criar uma caixa operária, mediante a expedição de ações de dez mil réis, com capital de mil contos de réis, que poderia ser ampliado, de acordo com a necessidade. Essa caixa deveria ser acessível aos operários de ambos os sexos, tendo fundo, gestão e regulamento próprios e objetivando à construção de casas de tamanho regular, que deveriam ser alugadas ou vendidas a operários, o que, sem dúvida alguma, constituía uma novidade no leque de serviços prestados pelas sociedades de socorros mútuos no Brasil.

A mesma norma previa a realização, em Salvador, de um congresso operário a cada três anos, a contar da data da instalação definitiva da organização, com o objetivo de "tomar as medidas que julgar consentâneas para o adiantamento geral dos operários, levantando as artes, os ofícios e as indústrias, e respeitando as leis federais e estaduais". Por fim, criava-se uma distinção entre os filiados, que poderiam ser agremiados ou associados. O primeiro pagaria $2 \$ 000$ de joia e $\$ 500$ de mensalidade, ao passo que o último teria que desembolsar uma joia de $5 \$ 000$ e mensalidades de $1 \$ 000$. Suspeitamos que essa distinção, na entidade, relacionava-se à extensão ou não de direitos políticos aos seus membros, mas isso não fica totalmente esclarecido. De todo modo, nos dois casos, a filiação era antecedida por uma investigação da conduta do candidato, na sociedade, e ele só adquiriria seus direitos legais, após um ano de contribuição, perdendo-os, após seis meses de inadimplência. Além disso, a Constituição do Centro Operário instituía outras três ordens de sócios: benfeitores, beneméritos e honorários, "sendo indiferente a classe a que pertençam, desde que,

\footnotetext{
${ }^{35}$ BATALHA, Claudio H. M. Sociedades de... op. cit.

${ }^{36}$ A concessão e a manutenção das pensões às viúvas estavam, expressamente, condicionadas a restrições morais, como se pode ver pelo art. 15, § 70: "Provado que a viúva não tem meio nenhum de vida, o Centro será obrigado a dar-lhe uma pensão mensal de $25 \$ 000$, sendo de $50 \$ 000$ no caso de morte, ficando ainda o mesmo Centro obrigado a aumentar os socorros, logo que seus recursos assim permitam, deixando, porém, de ser aplicadas estas disposições se chegar ao conhecimento do Centro que a viúva casou-se ou não vive honradamente". Grifos nossos.
} 
pelos serviços prestados à sociedade, tornem-se dignos de qualquer distinção". Uma distinção, aliás, era feita, também, aos operários que tomassem parte da primeira eleição do Centro Operário, pois receberiam o tratamento de "fundadores" e seus nomes seriam "gravados em um livro especial", o que, certamente, valia-Ihes algum capital político ${ }^{37}$.

O Centro Operário da Bahia tinha, pois, um caráter complexo e multifacetado. Ele atuava em esferas distintas: mutualismo, cooperativismo, mediação de conflitos entre capital e trabalho, defesa de interesses populares mais amplos, como, por exemplo, a luta contra a carestia dos gêneros de primeira necessidade e a especulação imobiliária. Por fim, o Centro Operário teve uma destacada e muito bem sucedida atuação nas lutas por cidadania para a classe operária por meio das eleições, inclusive, elegendo dezenas de seus membros para os cargos de juiz de paz e de conselheiro municipal de Salvador ao longo da Primeira República.

Um exemplo é o do pedreiro mestiço Domingos Francisco da Silva (1865-1914), importante figura no processo de fundação da organização em análise. Em 1890, integrou a direção do Partido Operário da Bahia, juntamente com o alfaiate Elysiario Elysio da Cruz, o ferreiro Francisco Pedro do Bomfim e o carpinteiro José Maria de Souza. Em 1893, foi o principal articulador da fundação do Centro Operário da Bahia, sendo eleito seu primeiro presidente. A patente de capitão da Guarda Nacional, certamente, deve ter funcionado como uma porta de entrada para a política no Império. Mas foi, sob a República, que Domingos Silva ocupou o cargo de auxiliar de obras públicas da Secretaria de Agricultura, Viação e Obras Públicas, entre 1896 e 1898, galgando à condição de "conhecido empreiteiro de obras" e ocupando vários cargos eletivos, em Salvador, como o de juiz de paz e membro da junta distrital de Santana e o de conselheiro do Conselho Municipal da capital baiana. Domingos Silva preservou elementos centrais da religiosidade, da cultura e da sociabilidade trazidas do Império, sendo irmão da Venerável Ordem Terceira do Rosário da Baixa dos Sapateiros, da Irmandade de São Benedito e da Irmandade da Conceição da Praia.

Um segundo caso é o do alfaiate e coronel da Guarda Nacional, Ismael Ribeiro dos Santos (1857-1931). Ele iniciou sua militância engajando-se, nas causas da Abolição e da República, e também foi um dos fundadores da Sociedade União Beneficente dos Alfaiates. Através de eleições, ele obteve votos suficientes para ser conduzido ao cargo de membro do Conselho Municipal de Salvador por duas vezes: a

\footnotetext{
${ }^{37}$ CONSTITUIÇÃO DO CENTRO OPERÁRIO DO ESTADO DA BAHIA. Diário da Bahia, Salvador, 8, 9 e 17 jun. 1894.
} 
primeira em 1896, quando ficou na suplência, e a segunda em 1903, quando logrou alçar a condição de titular.

Por último, citemos a situação do alfaiate e capitão da Guarda Nacional, Aurélio Sebastião Cardoso (1865-1915), que integrou inúmeras associações de auxílio mútuo e irmandades religiosas. Além da Sociedade União Beneficente dos Alfaiates, ele pertenceu à Sociedade Montepio dos Artífices, à Sociedade Filantrópica dos Artistas, à Sociedade Bolsa de Caridade, à Sociedade Bolsa dos Chapeleiros, à Sociedade Cooperativa dos Alfaiates e à Sociedade Beneficente dos Paroquianos da Sé, sem contar a Irmandade Nossa Senhora da Fé e Santa Cruz e a Irmandade São José do Corpo Santo. Por meio de bem construídas alianças das organizações operárias com os novos partidos das velhas elites, conseguiu se eleger três vezes para a Justiça de Paz do distrito da Sé $(12 / 11 / 1899,08 / 11 / 1903 \text { e 12/11/1911) })^{38}$.

\section{ORGANIZAÇÕES OPERÁRIAS POR EMPRESA E INICIATIVAS PATRONAIS}

Mesmo quando submetidos a uma disciplina do trabalho mais rígida e a uma maior vigilância patronal, situação típica das grandes empresas do século XIX e das primeiras décadas do $\mathrm{XX}$, segmentos importantes dos trabalhadores se organizaram e produziram um associativismo relativamente autônomo em relação aos patrões e ao Estado. Contudo, o surgimento das associações de auxílio mútuo (e sindicais) desses trabalhadores com pouca qualificação foi, relativamente, tardio quando comparada ao associativismo dos artesãos qualificados.

TABELA 2:

SOCIEDADES MUTUALISTAS / BENEFICENTES DE / POR EMPRESAS - BAHIA (1890-1930)

\begin{tabular}{|c|c|c|c|c|}
\hline Nome & Fundação & P. Notícia & Empresa & Cidade \\
\hline $\begin{array}{l}\text { Associação Geral de Auxílios Mútuos dos Empregados da } \\
\text { Estrada de Ferro do São Francisco }\end{array}$ & $10 / 09 / 1893$ & & $\begin{array}{l}\text { Estrada de Ferro do São } \\
\text { Francisco }\end{array}$ & Alagoinhas \\
\hline Sociedade Beneficente Vitória & $22 / 08 / 1894$ & & Fábrica de Charutos Vitória & Salvador \\
\hline $\begin{array}{l}\text { Sociedade Montepio Liga Operária dos Operários da Cia. } \\
\text { Valença Industrial }\end{array}$ & ??/??/1905 & & Cia. Valença Industrial & Valença \\
\hline Sociedade Beneficente da Chapelaria Norte Industrial & & 03/12/1906 & Chapelaria Norte Industrial & Salvador \\
\hline Sociedade Beneficente 24 de Julho & 04/04/1909 & & $\begin{array}{l}\text { Cia. Empório Industrial do } \\
\text { Norte }\end{array}$ & Salvador \\
\hline Sociedade Beneficente Valença Industrial & $08 / 12 / 1913$ & & Cia. Valença Industrial & Valença \\
\hline
\end{tabular}

38 Para uma análise mais detida do perfil desses artesãos, cf. CASTELLUCCI, Aldrin. Classe e cor na formação do Centro Operário da Bahia (1890-1930). Afro-Asia (UFBA), no 40, p. - , 2010 (no prelo). 


\begin{tabular}{|l|l|c|c|c|}
\hline Sociedade Beneficente 11 de Março & & ??/??/1916 & $\begin{array}{c}\text { Companhia União Fabril da } \\
\text { Bahia }\end{array}$ & Salvador \\
\hline $\begin{array}{l}\text { Sociedade Cooperativa e Auxiliadora dos Empregados da } \\
\text { Compagnie Chemins de Fer }\end{array}$ & $15 / 01 / 1918$ & & Compagnie Chemins de Fer & Salvador \\
\hline Sociedade Beneficente e Recreativa de São Brás & & $27 / 07 / 1919$ & $\begin{array}{c}\text { Fábrica São Brás - Cia. } \\
\text { Progresso Industrial da Bahia }\end{array}$ & Salvador \\
\hline $\begin{array}{l}\text { Sociedade Montepio dos Empregados da Estrada de Ferro de } \\
\text { Nazaré }\end{array}$ & & $29 / 01 / 1918$ & Estrada de Ferro de Nazaré & Nazaré \\
\hline $\begin{array}{l}\text { Associação dos Empregados da Companhia Ferroviária Este } \\
\text { Brasileiro }\end{array}$ & $28 / 01 / 1921$ & & $\begin{array}{c}\text { Companhia Ferroviária Este } \\
\text { Brasileiro }\end{array}$ & Salvador \\
\hline
\end{tabular}

Fontes: APEB, docs. cit. na tabela 1.

Um exemplo de esforço para se organizar, de forma independente, pode ser visto através da Associação dos Empregados da Companhia Ferroviária Este Brasileiro, fundada em 27 de janeiro de 1921, de acordo com os estatutos publicados no Diário Oficial do estado, de 19 de fevereiro de $1921^{39}$. Um segundo estatuto foi aprovado na sessão da assembleia geral do dia 23 de julho de 1923. Nele, declarava-se que a organização teria sido fundada, em 28 de janeiro de 1921, e que era constituída por todos os que prestassem serviços à Companhia. Seus objetivos eram a "defesa dos direitos e interesses da classe"; a garantia de assistência jurídica, nas ações intentadas por ou contra os associados, do auxílio funeral de duzentos mil réis, do pecúlio de quinhentos mil réis aos familiares dos associados falecidos e do auxílio máximo de cem mil réis aos filiados afastados de suas atividades laborais em função de problemas de saúde.

Por fim, a associação tinha, como seu último objetivo, manter uma "Caixa de Auxílio", com "vida própria e autônoma", destinada a "fazer adiantamentos" e a realizar "aquisição, construção ou reconstrução" de prédios para filiados. Por fim, parte dos lucros da "Caixa de Auxílio" deveria ser repassada para a associação que, por sua vez, reverteria tais recursos em favor de benefícios para seus associados ${ }^{40}$. Contudo, a iniciativa dos trabalhadores foi seguida por significativas investidas patronais, especialmente dos setores fabris e de transportes, com o objetivo de confinar seus empregados a um associativismo de caráter, puramente, assistencial e domesticado. Um caso limite que pode ser citado é o da Sociedade Beneficente 24 de Julho, instalada em 4 de abril de 1909, congregando os operários têxteis da Fábrica da Boa Viagem, pertencente à Companhia Empório Industrial do Norte (CEIN) ${ }^{41}$. A empresa controlava, não apenas, o caixa da entidade, formado por dotações

\footnotetext{
${ }^{39}$ ESTATUTOS da Associação dos Empregados da Companhia Ferroviária Este Brasileiro. DIÁRIO OFICIAL DO ESTADO DA BAHIA. Salvador: Imprensa Oficial do Estado da Bahia. 19 fev. 1921.

${ }^{40}$ Idem. Aprovados em sessão da assembleia geral de 23 de jun. de 1923. Bahia: Imprensa Oficial do Estado, 1923.

${ }^{41}$ ESTATUTOS da Sociedade Beneficente 24 de Julho dos Operários da Fábrica da Boa Viagem, a Companhia Empório Industrial do Norte. Instalada a 4 de abr. de 1909. Bahia: Typ. do Colégio São Joaquim, 1933.
} 
orçamentárias da Companhia e por descontos compulsórios nos salários dos operários, como também a própria diretoria da associação, composta por pessoas ligadas à administração da fábrica, como, por exemplo, o dr. Lino Meirelles da Silva, empossado como presidente da assembleia geral, e o dr. Adriano dos Reis Gordilho, empossado como presidente do diretório e sócio benemérito da Sociedade Beneficente 24 de Julho $^{42}$. O próprio nome da entidade lembrava e homenageava a data natalícia do industrial Luiz Tarquínio (1844-1903), fundador da CEIN ${ }^{43}$. Um segundo exemplo, também tirado do ramo têxtil, é o da Sociedade Beneficente da Companhia Valença Industrial (CVI), instalada na cidade de Valença, no dia 8 de dezembro de 1913. Seus estatutos afirmavam que a entidade teria sido instituída "sob os auspícios da Diretoria" da CVI e que, a ela poderiam se associar, voluntariamente, "todos os operários e empregados" da empresa que tivessem "vida honesta"44.

\section{A DIFÍCIL AUTONOMIA}

Mesmo quando os patrões não protagonizavam a criação de um associativismo para os trabalhadores sob sua tutela direta e explícita, algumas frações da classe trabalhadora enfrentaram sérias dificuldades para garantir autonomia em face do patronato e do Estado, fenômeno visível, no caso de empregados no comércio e dos funcionários públicos. Comecemos pelo caso dos empregados no comércio, que criaram várias sociedades recreativas e de ajuda mútua, desde meados do século XIX. Conforme pode ser visto, na Tabela 3, uma de suas primeiras e mais importantes associações de tipo mutualista foi a Sociedade Beneficência Caixeiral, fundada em 19 de abril de 1885. Tanto sua instalação solene quanto suas assembleias foram realizadas no salão nobre do Club Caixeiral, até maio de 1898 , quando a entidade transferiu-se para sua sede própria no Cruzeiro de São Francisco, Centro Histórico da cidade. A Beneficência Caixeiral propunha-se a atuar, não apenas, nas esferas mais comuns das associações de auxílio mútuo, como, por exemplo, na garantia dos funerais para os sócios falecidos, na assistência jurídica e na concessão de pensões por doença, desemprego ou invalidez. Ela se propunha, também, a envidar esforços visando a colocar os sócios desempregados no mercado de trabalho. Tendo em conta

\footnotetext{
42 DIÁRIO OFICIAL DO ESTADO DA BAHIA. Salvador: Imprensa Oficial do Estado da Bahia, p. 495-496, 2 jul. 1923. Edição Especial do Centenário.

${ }^{43}$ Diário de Notícias, Salvador, 26 abr. 1909, p. 7.

${ }^{44}$ ESTATUTOS da Sociedade Beneficente Valença Industrial. Instalada em 8 de dez. de 1913. Bahia: Typographia Bahiana, 1914.
} 
que Salvador era uma metrópole mercantil, os 88 sócios fundadores da entidade em 1885 compunham um grupo, relativamente, pequeno, que caiu para ínfimos 31 filiados em $1893^{45}$. Contudo, por razões desconhecidas, a Beneficência Caixeiral teve um impressionante aumento no número de seus membros nos anos seguintes, chegando a ter 1.075 sócios, em 1897, e uma média de 800 filiados entre 1900 e 1930. Ainda mais importante é destacar a dificuldade que os caixeiros enfrentaram para construir organizações independentes de seus patrões, com os quais compartilhavam, na maior parte das vezes, origens nacionais comuns e até laços de consanguinidade. Desde o início, a Sociedade Beneficência Caixeiral foi também composta e dirigida por comerciantes, alguns deles, inclusive, ocupantes de postos de mando na Associação Comercial da Bahia. Um exemplo é o do comerciante português Antonio da Costa Lino, que foi presidente da mesa da assembleia geral da Sociedade Beneficência Caixeiral, em 1904 e em 1906, e presidente de seu diretório em 1916. Outro caso emblemático é o de Bernardo Martins Catharino, também português, proprietário da Cia. União Fabril da Bahia e da Cia. Serraria e Construções, eleito vice-presidente da mesa de assembleia geral da Beneficência Caixeiral em $1925^{46}$.

Essa tendência não se alterou em função da criação de outras entidades. No dia 21 de janeiro de 1900, os caixeiros fundaram uma nova organização, em Salvador, a Associação dos Empregados no Comércio da Bahia (AECB). Sua penetração junto aos trabalhadores era, relativamente, grande e crescente. Em 1904, apenas quatro anos depois de instalada, ela já tinha mais de 700 filiados. Esse número subiu para mais mil,

\footnotetext{
${ }^{45}$ VIANNA, Francisco Vicente. Memória sobre... op. cit., p. 390. O Club Caixeiral foi fundado em 21 de maio de 1876 com a finalidade de patrocinar "instrução e recreação" aos seus sócios. ESTATUTOS do Club Caixeiral. Aprovados em sessão de assembleia geral de 26 de março de 1914. DIÁRIO OFICIAL DO ESTADO DA BAHIA. Salvador: Imprensa Oficial do Estado da Bahia, 27 mai. 1920.

46 RELATÓRIO da Sociedade Beneficência Caixeiral apresentado pelo Conselho Diretório em sessão da Assembléia Geral Ordinária em 16 de abril de 1899. Bahia: Officinas dos Dois Mundos, 1899.; RELATÓRIO da Sociedade Beneficência Caixeiral apresentado pelo Conselho Diretório em sessão da Assembléia Geral Ordinária em 15 de abril de 1900. Bahia: Imprensa Moderna de Prudêncio de Carvalho, 1900.; RELATÓRIO da Sociedade Beneficência Caixeiral apresentado pelo Conselho Diretório em sessão da Assembléia Geral Ordinária em 28 de abril de 1901. Bahia: Imprensa Moderna de Prudêncio de Carvalho, 1901.; RELATÓRIO da Sociedade Beneficência Caixeiral sobre o ano de 1904 apresentado pelo Conselho Diretório na sessão da Assembléia Geral de 25 de junho de 1905. Bahia: Imprensa Moderna de Prudêncio de Carvalho, 1905.; RELATÓRIO da Sociedade Beneficência Caixeiral sobre o ano de 1906 apresentado pelo Conselho Diretório na sessão da Assembléia Geral de 19 de maio de 1907. Bahia: Typographia do Lyceu de Artes, 1907.; RELATÓRIO da Sociedade Beneficência Caixeiral sobre o ano de 1911 apresentado pelo Conselho Diretório na sessão da Assembléia Geral de 24 de março de 1912. Bahia: Typographia e Encadernação do Lyceu de Artes e Offícios, 1912.; RELATÓRIO da Diretoria da Sociedade Beneficência Caixeiral referente ao exercício de 1916 apresentado a Assembléia Geral de 27 de abril de 1917. Bahia: Typographia e Encadernação do Lyceu de Artes e Offícios, 1917.; RELATÓRIO da Diretoria da Sociedade Beneficência Caixeiral. Exercício de 1925. Aprovado em Assembléia Geral de 21 de abril de 1926. Bahia: Officina Graphica Universal, 1926. e RELATÓRIO da Diretoria da Sociedade Beneficência Caixeiral. Exercício de 1928-1929. Apresentado à Assembléia Geral em 15 de abril de 1930. Bahia: Officinas Graphicas Fonseca Filho e C., 1930.
} 
em 1907, chegando a quase 1.200, em 1914, e a mais de 1.500, em 1917. Entre 1919 e 1923, reuniu mais de dois mil filiados e chegou a quase três mil membros em 1929. Além do auxílio para o funeral, das pensões por doença, por invalidez e por morte e da assistência jurídica, médica e odontológica, a AECB também buscava colocar os sócios desempregados no mercado de trabalho e mantinha uma biblioteca e escolas, nas quais oferecia cursos de escrituração mercantil, datilografia, matemática, português, inglês e francês. Mas, da mesma forma que havia ocorrido com a organização precedente, a AECB também teve suas ações e seus destinos, fortemente, influenciados pela intervenção patronal. Basta mencionarmos o fato de que os comerciantes portugueses Augusto Pinho e Antonio Manso, que foram da diretoria da Associação Comercial da Bahia, nos anos de 1914 a 1915 e de 1916 a 1918, também ocuparam a estratégica posição de presidente da AECB, no período de 1908-1909 e de 1918-1919, respectivamente. Além disso, de modo geral, as organizações dos caixeiros mostraram-se bem alinhadas com certos setores oligárquicos apoiados pela burguesia mercantil por ocasião das eleições, a exemplo do que ocorreu, na campanha de 1919, quando a candidatura presidencial de Ruy Barbosa foi, explicitamente, apoiada pelas entidades patronais e de empregados do comércio ${ }^{47}$.

${ }^{47}$ DIÁRIO OFICIAL DO ESTADO DA BAHIA. Salvador: Imprensa Oficial do Estado da Bahia, p. 475, 496496, 2 jul. 1923. Edição Especial do Centenário; RELATÓRIO apresentado pela Diretoria da Associação dos Empregados no Comércio da Bahia relativo à sua administração no ano de 1904 e aprovado em sessão de Assembléia Geral ordinária de 28 de maio de 1905. Bahia: Typographia Bahiana, 1905.; ASSOCIAÇÃO dos Empregados no Comércio da Bahia. Relatório apresentado pela sua Diretoria aprovado em sessão de Assembléia Geral ordinária de 12 de abril de 1908 relativo à administração do ano de 1907. Bahia: Typographia Bahiana, 1908.; RELATÓRIO apresentado pela Diretoria da Associação dos Empregados no Comércio da Bahia em sessão de Assembléia Geral Ordinária de 16 de maio de 1909 relativo à administração de 1908. Bahia: Typographia Bahiana, 1909.; RELATÓRIO apresentado pela Diretoria da Associação dos Empregados no Comércio da Bahia em sessão de Assembléia Geral Ordinária de 27 de fevereiro de 1916 relativo à administração do ano de 1915. Bahia: Typographia Bahiana, 1916.; RELATÓRIO apresentado pela Diretoria da Associação dos Empregados no Comércio da Bahia em sessão de Assembléia Geral Deliberativa de 24 de fevereiro de 1918 relativo à administração de 1916 e 1917. Bahia: Estabelecimento dos Dois Mundos, 1918.; RELATÓRIO apresentado pela Diretoria da Associação dos Empregados no Comércio da Bahia em sessão de Assembléia Deliberativa de 7 de março de 1920 relativo à administração de 1918 e 1919. Bahia: Officinas da Livraria "Duas Américas", 1920.; RELATÓRIO apresentado pela Diretoria da Associação dos Empregados no Comércio da Bahia em sessão de Assembléia Deliberativa de 1 de abril de 1928 relativo à administração de 1926 a 1927. Bahia: Livraria e Typographia do Commercio, 1928. e RELATÓRIO apresentado pela Diretoria da Associação dos Empregados no Comércio da Bahia em sessão de Assembléia Deliberativa de 27 de abril de 1930. Relativo à administração de 1928 a 1929. Bahia: Livraria e Typographia do Commercio, 1930. 
TABELA 3:

SOCIEDADES DE EMPREGADOS NO COMÉRCIO / SERVIÇOS - BAHIA (1832-1930)

\begin{tabular}{|c|c|c|c|c|}
\hline Nome & Fundação & Reorganização & P. Notícia & Cidade \\
\hline $\begin{array}{l}\text { Sociedade Montepio dos Caixeiros Nacionais (Depois } \\
\text { convertida em Montepio Geral da Bahia) }\end{array}$ & $22 / 11 / 1857$ & ??/??/1870 & & Salvador \\
\hline Clube Caixeiral & $21 / 05 / 1876$ & $16 / 03 / 1914$ & & Salvador \\
\hline Sociedade Beneficência Caixeiral & 19/04/1885 & $30 / 03 / 1917$ & & Salvador \\
\hline Associação dos Empregados do Comércio da Bahia & $21 / 01 / 1900$ & & & Salvador \\
\hline $\begin{array}{l}\text { Sociedade de Beneficência dos Empregados de } \\
\text { Restaurantes }\end{array}$ & $20 / 06 / 1900$ & & & Salvador \\
\hline Associação B. dos E. no Comércio de Feira de Santana & & & 29/10/1903 & F. de Santana \\
\hline Associação dos Empregados em Restaurantes & & & ??/??/1903 & Salvador \\
\hline Clube Caixeiral Amargosense & & & $11 / 06 / 1904$ & Amargosa \\
\hline Clube Caixeiral de Santo Amaro & & & $27 / 05 / 1905$ & Santo Amaro \\
\hline Associação dos Empregados no Comércio de Ilhéus & $23 / 01 / 1908$ & & & Ilhéus \\
\hline Sociedade União Beneficente Caixeiral de Itabuna & $31 / 10 / 1908$ & & & Itabuna \\
\hline Associação dos Empregados no Comércio do Ventura & & & 05/02/1909 & Ventura \\
\hline Beneficência Caixeiral de Belmonte & & & $12 / 10 / 1911$ & Belmonte \\
\hline S. União dos Empregados do Comércio Varejista & $15 / 11 / 1915$ & & & Salvador \\
\hline União Caixeiral da Bahia & 01/06/1919 & & & Salvador \\
\hline União Caixeiral de Santo Antônio de Jesus & $11 / 06 / 1920$ & & & S. A. de Jesus \\
\hline Associação dos Empregados no Comércio de Ilhéus & $01 / 08 / 1920$ & & & Ilhéus \\
\hline Clube Caixeiral “Afrânio Peixoto” & & & $27 / 09 / 1924$ & Salvador \\
\hline Associação dos Caixeiros Viajantes da Bahia & $17 / 11 / 1925$ & 02-04/09/1936 & & Salvador \\
\hline
\end{tabular}

Fontes: APEB, docs. cit. na tabela 1.

Os funcionários públicos constituíam outro setor com dificuldades para se organizar de forma independente, dado que as contratações eram feitas sem obediência a critérios, estritamente, técnicos e, no interior, de redes de clientela. A posição politicamente fragilizada desses trabalhadores em relação aos governos se refletia em suas organizações, dirigidas e controladas por altos mandatários do Estado e por elementos de destaque das elites. Algumas entidades foram fundadas através da iniciativa do próprio governo, que as impôs aos trabalhadores. Esse foi o caso do Montepio dos Funcionários do Município da Cidade do Salvador, instituído por meio da Resolução n. 14, de 15 de abril de 1893, do Conselho Municipal. A sociedade era mantida através dos descontos compulsórios feitos, nos salários dos servidores municipais efetivos (ativos ou inativos), e tinha por objetivo garantir uma pensão às famílias dos sócios que falecessem. A entidade era dirigida por um conselho integrado por ocupantes de cargos de chefia da administração soteropolitana, presidido pelo intendente municipal ${ }^{48}$.

\footnotetext{
${ }^{48}$ Lei no. 1.202, de 31 de dezembro de 1928. Regula o Montepio dos Funcionários Municipais, instituído pela resolução no. 14, de 15 de abril de 1893. Bahia: Imprensa Oficial do Estado, 1929.
} 
TABELA 4:

ASSOCIAÇÕES DE FUNCIONÁRIOS PÚBLICOS - SALVADOR (1884-1927)

\begin{tabular}{|c|c|c|c|}
\hline Nome & Fundação & P. Notícia & Cidade \\
\hline Associação de Socorros Mútuos dos Empregados Provinciais & & & Salvador \\
\hline Sociedade Beneficente dos Empregados da Tesouraria de Fazenda & ??/??/1884 & & Salvador \\
\hline Associação Beneficente dos Funcionários Públicos & $09 / 01 / 1887$ & & Salvador \\
\hline Sociedade Beneficente Montepio dos Empregados Municipais da Capital da Bahia & ??/05/1890 & & Salvador \\
\hline Montepio dos Empregados do Estado & ??/08/1891 & & Salvador \\
\hline Montepio dos Funcionários Municipais & $15 / 04 / 1893$ & & Salvador \\
\hline Grêmio Beneficente do Professorado Baiano & $25 / 03 / 1898$ & & Salvador \\
\hline Sociedade Beneficente Telegráfica & $01 / 01 / 1898$ & & Salvador \\
\hline Sociedade Beneficente União dos Carteiros do Correio da Bahia & ??/09/1904 & & Salvador \\
\hline Sociedade Fraternal do Corpo de Bombeiros & & 03/11/1904 & Salvador \\
\hline Sociedade Beneficente do Regimento Policial & $14 / 02 / 1905$ & & Salvador \\
\hline Sociedade Cooperativa dos Funcionários Públicos e Procuradores do Estado da Bahia & 29/08/1905 & & Salvador \\
\hline Sociedade Beneficente União dos Postilhões & $16 / 07 / 1906$ & & Salvador \\
\hline Sociedade Beneficente dos Carteiros da Bahia & & 20/08/1906 & Salvador \\
\hline Sociedade Beneficente União dos Carteiros do Correio da Bahia & 08/09/1909 & & Salvador \\
\hline Cooperativa Municipal & 06/01/1911 & & Salvador \\
\hline Liga dos Funcionários Federais da Bahia & 29/08/1914 & & Salvador \\
\hline Sociedade Beneficente dos Empregados do Telégrafo Nacional na Bahia & $17 / 09 / 1916$ & & Salvador \\
\hline Caixa Beneficente dos Funcionários da Faculdade de Medicina da Bahia & $01 / 07 / 1917$ & & Salvador \\
\hline Sociedade Beneficente dos Funcionários da Justiça & 13/05/1918 & & Salvador \\
\hline Associação dos Funcionários Públicos do E. da Bahia & 20/08/1918 & & Salvador \\
\hline Sociedade Beneficente dos Sargentos da Força Policial do E. da Bahia & $02 / 02 / 1927$ & & Salvador \\
\hline
\end{tabular}

Fontes: APEB, docs. cit. na tabela 1.

No início da República, os funcionários públicos estaduais também foram arregimentados para uma associação, o Montepio dos Empregados do Estado, que não havia nascido através de sua iniciativa e cuja manutenção seria feita com base em filiações obrigatórias e em descontos compulsórios nos proventos dos servidores. 0 projeto para a criação dessa entidade foi apresentado à Câmara dos Deputados da Bahia, em agosto de 1891, pelo farmacêutico e jornalista Amaro de Lellis Piedade (1856-1908) e garantiria auxílio para o funeral e pensões aos familiares dos sócios falecidos ${ }^{49}$.

A despeito disso, os servidores públicos das três esferas de poder também tomaram a iniciativa de criação de associações de auxílio mútuo, embora, na maioria das vezes, isso não redundasse em organizações autônomas do governo e do estado. 0 caso da Associação dos Funcionários Públicos do Estado da Bahia (AFPEB), fundada, em 20 de agosto de 1918 e, solenemente, instalada, em 8 de setembro do mesmo ano, é emblemático. É interessante observar que, apesar de ter sido, formalmente, concebida como associação de auxílio mútuo, sua atuação inicial mais destacada e visível foi no campo das lutas por melhores salários para os servidores ${ }^{50}$.

A situação dos funcionários públicos era muito difícil, pois seus salários não haviam tido qualquer reajuste, desde 1 o de maio de 1896, ou seja, tomando 1918

\footnotetext{
49 Jornal de Notícias, Salvador, 1, 3, 4, 5 e 8 ago. 1891.

${ }^{50}$ O Tempo, Salvador, 17 e 19 jul. 1918.; Idem, 8, 21 e 27 ago. 1918. e DIÁRIO OFICIAL DO ESTADO DA BAHIA. Salvador: Imprensa Ofical do estado da Bahia, 10 set. 1918.
} 
como referência, ${ }^{51}$ estavam estagnados há 22 anos. Foi nesse quadro de descontentamento generalizado que se aprovou, em agosto de 1918, a lei no 1.286. Através dela, o governo do estado concedia uma gratificação especial a vigorar, durante a fase final da guerra, como forma de compensar a queda do poder de compra dos salários em face da carestia geral. As gratificações variaram entre $8 \%, 10 \%$ e $12 \%$ e incidiriam sobre os proventos (salários ou diárias) de todos os funcionários e serventuários do estado, inclusive os da Câmara dos Deputados e do Senado do estado, excluídos do gozo de tais vantagens o governador, os deputados, os senadores e os comissionados. Já os 1.000 praças da Força Pública, lotados em Salvador, receberiam uma gratificação extraordinária de 300 réis diários. ${ }^{52}$ Mas, a corrosão dos salários era tanta que, já em agosto de 1919, a AFPEB reivindicou 30\% de aumento, enquanto a Câmara dos Deputados do estado discutia o projeto no 111, que previa a incorporação definitiva da gratificação de guerra aos salários dos funcionários públicos baianos. $^{53}$

O Projeto de Estatutos da Associação dos Funcionários Públicos do estado da Bahia, publicado no Diário Oficial, por meio das emendas feitas nas assembleias de fundação e de instalação da entidade, estabelecia para si, entre outros, os seguintes objetivos: "promover a defesa dos direitos e interesses da classe"; prestar assistência médica aos sócios e a seus familiares, inclusive, com o fornecimento de medicamentos; "custear ou auxiliar as despesas judiciárias nas ações intentadas pelos sócios ou contra eles promovidas"; fornecer às famílias dos associados um auxílio funeral no valor duzentos mil réis; auxiliar a educação dos filhos dos sócios por meio da garantia de vestuário, de livros e de matrículas, em estabelecimentos de ensino secundário, superior ou profissional, desde que ele revelasse "vocação", "irrepreensível aplicação" e provasse "escassez de recursos". Cada funcionário deveria pagar uma joia de dez mil réis, no momento da filiação, e uma mensalidade de dois mil réis a serem descontados, em folha de pagamento, pelo Tesouro do Estado. Era facultado aos sócios inscrever-se, também, na Caixa de Beneficência da AFPEB, pagando mais dois mil réis a cada vez que um sócio falecesse (até o limite de dois por mês). Se optasse por esse sistema, além dos benefícios anteriormente mencionados, a

\footnotetext{
${ }^{51}$ ATA da 2a Reunião de Assembléia Geral Extraordinária da Associação dos Funcionários Públicos do Estado da Bahia de 16 de jun. de 1919. DIÁRIO OFICIAL DO ESTADO DA BAHIA. Salvador: Imprensa Ofical do estado da Bahia, 22 jun. 1919.; A Tarde, Salvador, 19 jun. 1918, p. 1. Esse reajuste de 1896 ocorreu em função da primeira reforma nos quadros do funcionalismo tendo por base a Lei no 115 , de 16 de agosto de 1895.

52 BAHIA. Lei no 1.286, de 24 de agosto de 1918. Coleção de Leis do Estado da Bahia do ano de 1918. Salvador: Imprensa Oficial do Estado, pp. 30-31, 1921. e DIÁRIO OFICIAL DO ESTADO DA BAHIA. Salvador: Imprensa Ofical do estado da Bahia, 27 ago. 1918.

${ }^{53}$ A Hora, Salvador, 10 ago. 1919, p. 1 e lbidem, 12 de ago. 1919, p. 2.
} 
família do associado que morresse teria direito ao total dos valores resultantes da multiplicação das contribuições extraordinárias pelo número de filiados da Caixa de Beneficência $^{54}$.

A adesão dos servidores públicos à AFPEB foi, relativamente, grande, embora desigual quando comparamos as duas caixas da Associação. No final de novembro de 1918, portanto, três meses após sua fundação, a AFPEB já contava 668 filiados ${ }^{55}$. No começo de junho de 1919, o número total de sócios da entidade era de 686, sendo 667 da capital e 19 do interior. Deduzidos os doze falecimentos ocorridos, havia 674 membros. A Caixa de Beneficência tinha 444 inscritos, número que caiu para $436 \mathrm{em}$ função dos oito falecimentos ocorridos. Ao final dos primeiros nove meses de existência, a receita total da AFPEB era de 24:793\$860, ao passo que a despesa era de apenas 3:250\$500, restando-Ihe um robusto saldo de 20:020\$000. A Caixa de Beneficência teve receita de 10:105\$884, despesa de 5:662\$000 e saldo de 4:356\$684. Em resumo, entre setembro de 1918 e junho de 1919, a Associação e a Caixa, juntas, tiveram despesas de 3:800\$000 com lutos e funerais, 4:062\$000 com gastos em pecúlios e saldo de 25:992\$244. Não foi sem razão que os servidores públicos municipais e federais solicitaram adesão à AFPEB, pagando joias e duas mensalidades adiantadas por bimestre como garantia de adimplência. Além disso, a entidade recebeu o pedido de transferência de fundos sociais e de filiados da antiga Associação de Socorros Mútuos dos Empregados Provinciais para a AFPEB. As duas propostas foram recomendadas pela diretoria e aprovadas pela assembleia ${ }^{56}$.

A solidez financeira e o número de adesões à AFPEB tenderam a crescer nos anos seguintes. Em dezembro de 1919, ela tinha um saldo de quase 53 contos de réis e já contava com 494 inscritos na Caixa de Beneficência e com 821 membros na Associação, incluindo 7 funcionários federais e 47 municipais. Excluindo os sócios que morreram ao longo do exercício, as filiações caíam para 475 e para 802, respectivamente. ${ }^{57}$ No final de 1920, já eram 864 filiados à Associação e 522 inscritos na Caixa de Beneficência, números que caiam para 808 e para 480 quando deduzidos

\footnotetext{
${ }^{54}$ Projeto de Estatutos da Associação dos Funcionários Públicos do Estado da Bahia (Redigido de acordo com as emendas). In: DIÁRIO OFICIAL DO ESTADO DA BAHIA. Salvador: Imprensa Ofical do estado da Bahia, 15 ago. 1918.

${ }^{55}$ Relação dos sócios da Associação dos Funcionários Públicos do Estado da Bahia até 30 de novembro de 1918. In: Ibidem, 4 dez. 1918.

${ }^{56}$ Exposição da Diretoria da Associação dos Funcionários Públicos do Estado da Bahia feita a Assembléia Geral Extraordinária em 5 de jun. de 1919. In: Ibidem, 11 jun. 1919.; Acta da 2a reunião de Assembléia Geral extraordinária da Associação dos Funcionários Públicos do Estado da Bahia. In: Ibidem, 22 jun. 1919.

${ }^{57}$ Relatório apresentado à Assembléia Geral da Associação dos Funcionários Públicos do Estado da Bahia, em 20 de março de 1920, pelo Dr. Manoel Luiz do Rego, Presidente da Diretoria. In: Ibidem, 11 mar. 1920.
} 
os falecimentos. Em seu relatório, a diretoria gabava-se de que a situação financeira da Associação e da Caixa de Beneficência era "francamente sólida e promissora", já que a primeira tinha um saldo líquido de 58:688\$259 e a última possuía 4:767\$10958.

De todo modo, é preciso mencionar que, em alguma medida, a prosperidade da AFPEB se devia às boas relações que sua direção tinha com o governo, traduzidas, inclusive, nas graças que o estado dava-lhes, na forma de isenções de impostos e de subvenções de quatro contos de réis anuais entre 1920 e 1925. Além disso, a cultura política dos servidores públicos era muito influenciada pelo comportamento das elites políticas oligárquicas da Primeira República. Basta dizer que o dr. Manoel Luiz do Rego foi, sucessivamente, empossado presidente da Associação, entre 1918 e 1921, chegando a ser aclamado seu presidente perpétuo em 1922.

\section{CURTO-CIRCUITO IDENTITÁRIO}

Diferente do que ocorreu em São Paulo ou no Sul, regiões que receberam boa parte dos 3.390.000 imigrantes estrangeiros que aportaram no Brasil entre $1871 \mathrm{e}$ $1920^{59}$, não houve fluxos migratórios internacionais significativos para a Bahia. Em 1920, os estrangeiros eram apenas 10.600 em todo o estado, ou seja, 0,3\% da população total, formada por 3.334.465 habitantes. Em Salvador, esse percentual aumentava, pois a capital concentrava a maior parte dos imigrantes, mas não o suficiente para alterar, significativamente, o quadro acima mencionado. Os 7.763 estrangeiros que viviam na capital baiana representavam apenas $2,7 \%$ de sua população total. As maiores e mais importantes colônias eram, sem dúvida, as de Portugal, Espanha e Itália, sendo que, em sua maioria, esses estrangeiros eram caixeiros ou comerciantes ${ }^{60}$.

\footnotetext{
${ }^{58}$ Relatóario da Associação dos Funcionários Públicos do Estado da Bahia apresentado à Assembléia Geral em 30 de março de 1921, pelo Dr. Manoel Luiz do Rego, Presidente da Diretoria. In: Ibidem, 20 mar. 1921.

${ }^{59}$ Em 1893, os imigrantes já correspondiam a 54,6\% da população total da capital paulista, sendo 85,5\% dos artesãos, $79 \%$ dos operários das manufaturas, $81 \%$ dos trabalhadores dos transportes e $71,6 \%$ dos empregados do comércio. Em seu conjunto, os imigrantes dominavam 71,2\% da força de trabalho total da cidade. MARAM, Sheldon Leslie. Anarquistas, imigrantes e o movimento operário brasileiro (18901920). Rio de Janeiro: Paz e Terra, 1979, pp. 13 e 15-16.

${ }^{60}$ Em 1920, o número de habitantes das colônias estrangeiras, na Bahia, eram os seguintes: Alemanha: 398; França: 419; Espanha: 2.489; Inglaterra: 240; Itália: 1.448; Portugal: 3.345; Rússia: 152; outras nacionalidades: 2.109. Para Salvador, os números eram os seguintes: Alemanha: 291; França: 325; Espanha: 2.314; Inglaterra: 214; Itália: 606; Portugal: 2.653; Rússia: 138; outras nacionalidades: 1.222. Recenseamento do Brasil realizado em 1 o de setembro de 1920. Rio de Janeiro: Tipografia da Estatística, 1927, v. IV (1a Parte - População). P. 52-53; 308-311; 598-601; Rio de Janeiro: Tipografia da Estatística, 1927, v. IV (2a Parte - População). p. 6.
} 
TABELA 5:

ASSOCIAÇÕES MUTUALISTAS ÉTNICO-NACIONAIS (1849-1930)

\begin{tabular}{|l|c|c|c|c|}
\hline \multicolumn{2}{|c|}{ Fundação } & Reorganização & P. Notícia & Cidade \\
\hline Sociedade Italiana de Mútuos Socorros & & $28 / 06 / 1903$ & ??/??/1849 & Salvador \\
\hline Sociedade Portuguesa de Beneficência 16 de Setembro & $01 / 01 / 1857$ & & & Salvador \\
\hline Sociedade de Beneficência Portuguesa & $20 / 09 / 1857$ & & & Salvador \\
\hline Societé Suisse de Bienfaisance & & & ??/??/1857 & Salvador \\
\hline Real S. Portuguesa de Beneficência 16 de Setembro & $14 / 08 / 1859$ & & & Salvador \\
\hline Societá Italiana di Recreazione e Beneficenza in Bahia & $03 / 03 / 1861$ & ??/??/1863 & & Salvador \\
\hline Sociedade Beneficência Italiana & $25 / 01 / 1863$ & & & Salvador \\
\hline Societé Française de Bienfaisance & $09 / 02 / 1868$ & & & Salvador \\
\hline Deutscher Hilfsverein & $28 / 08 / 1868$ & & & Salvador \\
\hline Sociedade Espanhola de Beneficência & $01 / 01 / 1885$ & & & Salvador \\
\hline
\end{tabular}

Fontes: APEB, docs. cit. na tabela 1.

Ainda assim, várias associações de auxílio mútuo de diversas nacionalidades foram criadas, na Bahia, no século XIX. A maior parte dessas entidades era muito pequena, refletindo o tamanho das colônias estrangeiras em solo baiano. A Deutscher Hilfsverein, por exemplo, foi fundada em 28 de agosto de 1868, e contava com apenas 59 sócios alemães. A Societé Française de Bienfaisance foi criada em 9 de fevereiro de 1868, e tinha, somente, 30 filiados franceses. Os italianos fundaram, pelo menos, três associações, na Bahia, sobre as quais sabemos muito pouco. A primeira foi a Sociedade Italiana de Mútuos Socorros, criada em torno de 1849. A segunda foi a Societá Italiana di Recreazione e Beneficenza in Bahia, criada em 3 de março de 1861. A terceira foi a Sociedade Beneficência Italiana, instituída em 25 de janeiro de 1863. Sobre ela temos algumas informações. Sua sede ficava no primeiro andar de um prédio alugado, na rua Chile, n. 32. Na sede, havia retratos dos reis Vittorio Emanuel II, Umberto I e Vittorio Emanuel III, de Cavour e de Garibaldi. Em 1893, três décadas depois de fundada, essa associação contava com apenas 53 sócios, número que subiu para 90 em julho de $1906^{61}$.

As associações criadas pelos espanhóis e pelos portugueses tenderam a ser bem maiores e mais sólidas. Os portugueses foram os primeiros. No dia 1 de janeiro de 1857, eles fundaram a Sociedade Portuguesa Dezesseis de Setembro. A sociedade contava 47 signatários, havendo indícios de que alguns eram empregados no comércio. Em setembro de 1858, o número de sócios havia aumentado para 153. Ocorre que a colônia portuguesa, na Bahia, estava divida por causa de um assunto sobre o qual não temos conhecimento. Por isso, uma outra associação, intitulada Sociedade Portuguesa de Beneficência, foi criada em 20 de setembro de 1857. Sua

\footnotetext{
${ }^{61}$ VIANNA, Francisco Vicente. Memória sobre... op. cit., pp. 394-395.; APEB, Seção de Arquivo Colonial e Provincial, Presidência de Província, maço 1575. e Diário de Notícias, Salvador, 23 jul. 1906, p. 3.
} 
sessão de instalação foi feita, na sede da Sociedade Montepio da Bahia, foi secretariada pelo chanceler Gregório Ancelmo Ribeiro Marques e contou com a presença do cônsul de Portugal, o comendador José Agostinho de Salles, além do negociante Theodoro José Pires de Castro. De todo modo, foram feitos esforços de ambos os lados para a fusão das duas entidades, o que, efetivamente, ocorreu, em 14 de agosto de 1859, quando a organização passou a se chamar Sociedade Portuguesa de Beneficência Dezesseis de Setembro. Por meio de seus estatutos (1861), a Sociedade Portuguesa de Beneficência declarava que seus fins eram os seguintes: "comemorar o dia 16 de setembro", aniversário natalício de d. Pedro V, rei de Portugal; fornecer agasalho, curativo e sustento aos sócios necessitados e a suas famílias; "proporcionar ocupação lícita aos sócios desempregados segundo suas habilitações"; "auxiliar, conforme as suas forças o permitirem, os portugueses indigentes" e "empregar os meios ao seu alcance para que os portugueses de procedimento irregular se corrijam e se empreguem em trabalho honesto". A adesão de novos filiados não obedeceria a distinções profissionais ou à posição social, mas se exigia que o candidato a sócio fosse reputado como alguém que tinha "ocupação lícita" e "bons costumes". Em 1862, d. Luiz I, rei de Portugal, declarou-se protetor da Sociedade, conferindo-lhe, em 1863, o título de Real Sociedade Portuguesa de Beneficência Dezesseis de Setembro. A partir de então, a associação tendeu a crescer de modo significativo. No biênio 1863-1864, entraram 306 novos filiados, perfazendo um total de 1.231 sócios $^{62}$.

Os relatórios da Real Sociedade Portuguesa de Beneficência Dezesseis de Setembro, que revelavam sua situação, nas primeiras décadas do século $X X$, nos mostram um quadro mais complexo. O número de sócios continuou significativo, os serviços prestados pela associação parecem ter sido melhorados e ampliados, mas havia indícios de desequilíbio em suas contas. Tudo indica que a entidade apostou alto demais em uma sobrevivência baseada em fontes alternativas de receita. Tanto que as mensalidades de seus filiados pesavam, cada vez menos, no conjunto de sua receita. No relatório do exercício de 1900-1901, o número total de associados era de 1.128, mas apenas 109 eram efetivos (contribuintes), ao passo que 897 eram remidos, 72 eram benfeitores e 50 eram beneméritos. Entre as causas apontadas pela diretoria, estava a diminuição da imigração portuguesa para a Bahia, provocando a interrupção do fornecimento de novos sócios para a organização e seu lento decréscimo, em

\footnotetext{
${ }^{62}$ REAL Sociedade Portuguesa de Beneficência 16 de Setembro - 1857-1957. Um Século de Existência. Salvador: Tipografia Menú Editora Ltda., 1957.; ESTATUTOS da Sociedade Portuguesa de Beneficência Dezesseis de Setembro na Bahia. Aprovados elo Governo. Bahia: Typographia Poggetti do Jornal da Tarde, 1861.
} 
termos associativos e de rendimentos. Além disso, a diretoria alegou que foi obrigada a fazer uso recorrente da verba de donativos em função da elevação constante das despesas da entidade. Por fim, a diretoria explicitou que esses fatos ainda teriam sido agravados pela profunda crise financeira que atingiu a Bahia, no período de sua gestão, inclusive, com a desvalorização das ações de bancos que a entidade possuía ${ }^{63}$.

Ao fazer o balanço dos exercícios de 1906-1909, a diretoria da Real Sociedade Portuguesa de Beneficência Dezesseis de Setembro reiterou as afirmações anteriores quanto à fragilidade da imigração lusitana para a Bahia, comparando-a com a pujança do processo, em outros estados da federação, e destacando os prejuízos desse fato para a oxigenação da entidade com novos associados. Em 1909, ela possuía 1.004 associados, sendo que, tão somente, 83 eram efetivos, enquanto 833 eram remidos, 50 constavam como benfeitores e 38 estavam na lista dos beneméritos ${ }^{64}$.

Nos anos que se seguiram, a sustentação da entidade continuou a ser garantida pelos rendimentos das aplicações financeiras que detinha nos bancos, pelos serviços prestados e pelos donativos feitos por indivíduos das elites portuguesas em solo baiano, inclusive, os sócios benfeitores e beneméritos, pelos espólios legados por sócios falecidos que eram bem situados na hierarquia social de Salvador e pelas subvenções dadas pelo consulado de Portugal na Bahia. Ao final do biênio 1910-1911, a Real Sociedade Portuguesa de Beneficência registrou a existência de 1.031 filiados, sendo 93 contribuintes, 846 remidos, 46 benfeitores e 46 beneméritos ${ }^{65}$. Ao cabo do biênio 1916-1918 o número de sócios contribuintes diminuiu ainda mais: os efetivos passaram a ser ínfimos 46, enquanto os remidos aumentaram para 957 e os benfeitores e beneméritos eram 35 e 40 sócios, respectivamente. ${ }^{66}$

Os espanhóis que vieram para a Bahia fundaram a Socíedad Española de Beneficencia, no dia 1 de janeiro de 1885, contando 124 só1.133 associados em 1923, sendo 612 remidos e 621 ativos, isto é, contribuintes. Esse é um detalhe importante, podendo ser um indicador de que a associação dos espanhóis fosse menos

\footnotetext{
${ }^{63}$ RELATÓRIO da Diretoria da Real Sociedade Portuguesa de Beneficência Dezesseis de Setembro no Exercício de 1900 a 1901. Apresentado à Assembléia Geral em sessão ordinária de 15 de dez. de 1901. Bahia: Lytho-Typo V. Oliveira e C., 1901.

${ }^{64}$ RELATÓRIO da Diretoria da Real Sociedade Portuguesa de Beneficência Dezesseis de Setembro nos Exercícios de 1906 a 1909. Apresentado à Assembléia Geral em sessão ordinária de 29 de maio de 1910. Bahia: Officinas dos Dois Mundos, 1910.

${ }^{65}$ RELATÓRIO da Diretoria da Real Sociedade Portuguesa de Beneficência Dezesseis de Setembro no Exercício de 1910 a 1911. Apresentado à Assembléia Geral em sessão ordinária de 26 de janeiro de 1912. Bahia: Officinas dos Dois Mundos, 1912.

${ }^{66}$ RELATÓRIO da Diretoria da Real Sociedade Portuguesa de Beneficência Dezesseis de Setembro no Exercício de 1910 a 1911. Apresentado à Assembléia Geral em sessão ordinária de 22 de junho de 1919. Bahia: Officinas da Livraria Duas Américas, 1919.
} 
dependente dos recursos que lhe chegavam de fora do que o grêmio dos portugueses. ${ }^{67}$

Ao analisar o peso do componente nacional na história do movimento operário internacional, Eric Hobsbawm havia advertido que as classes operárias de todos os países tendiam a ser heterogêneas e com identificações múltiplas, que uma identidade não necessariamente excluía outras - embora algumas se sobressaíssem mais do que as demais em determinadas épocas - e que as lealdades mudavam com o passar do tempo e de acordo com o contexto da ação. Para esse historiador, em geral, quando as identidades étnico-nacionais ou religiosas surgiam antes da identidade de classe, elas representavam uma séria ameaça ou empecilho ao desenvolvimento desta última. Contudo, quando o caminho percorrido era o oposto, ou seja, quando a primeira identificação era construída por meio do referencial social e profissional, essa identificação não parecia significar uma barreira às outras identidades, que tendiam a se tornar secundárias à medida que avançava a consciência de classe ${ }^{68}$.

Essa parece uma questão que diz respeito às associações de auxílio mútuo dos imigrantes que vieram para o Brasil. Ainda não há estudos sobre essa associatividade, mas os dados que obtivemos nos permitem dizer que a identidade nacional dos imigrantes que aportaram, na Bahia, combinadas com laços de consanguinidade e com outros fatores, justapôs-se à identidade de classe dos trabalhadores que integravam aqueles grêmios, obstruindo-a, mesmo que parcialmente. Não sem razão, essas entidades foram dominadas, desde o início, pelo paternalismo das pessoas que ocupavam posições superiores na hierarquia social de Salvador, resultando no não questionamento formal (estatutário) ou prático das desigualdades sociais existentes no Brasil, inclusive, as que colocavam, em campos distintos, os próprios membros das associações, já que elas abrigavam tanto os empregados quanto os empregadores, contanto que tivessem a mesma origem nacional.

\footnotetext{
${ }^{67}$ MEMORIA de la Socíedad Española de Beneficencia presentada por la Junta Directiva de 1899 a 1900 siendo Presidente Manoel Alvarez y Alvarez. Bahia: Imprensa Moderna de Prudencio de Carvalho, 1901.; VIANNA, Francisco Vicente. Memória sobre... op. cit., p. 475; Diário de Notícias, Salvador, 28 jan. 1907, p. 2. e Idem, 6 fev. 1911, p. 2.

${ }^{68}$ HOBSBAWM, Eric J. Qual o país dos trabalhadores? In: Ibidem. Mundos do trabalho: novos estudos sobre história operária. Tradução de Waldea Barcellos e Sandra Bedran. Rio de Janeiro: Paz e Terra, 1987, pp. 79-97.
} 


\section{CONCLUSÃO}

Em nosso artigo, apresentamos uma cartografia do associativismo mutualista, na Bahia, entre 1832 e 1930. Nosso intento, com esse mapeamento, foi despertar, nos historiadores profissionais e nos aprendizes do ofício, a oportunidade de se debruçarem sobre um fenômeno quase que, absolutamente, inexplorado em suas mais variadas dimensões. Se comparado ao que existe para outras regiões do país, quase tudo está por ser feito entre nós, principalmente, se levarmos em conta os ganhos teóricos e metodológicos da historiografia do trabalho a partir dos anos 1990. Em última instância, está lançado o apelo para que sejam feitas dissertações de mestrado e teses de doutorado sobre o assunto. Se isso ocorrer, nos daremos por satisfeitos com essas notas de pesquisa. 
ANEXOS

TABELA 7:

NÚMERO DE SÓCIOS DE ALGUMAS ASSOCIAÇÕES DE AUXÍLIO MÚTUO - BAHIA, 1832-1930

\begin{tabular}{|c|c|c|c|c|c|c|c|c|c|c|c|c|c|}
\hline Sociedade & $\begin{array}{c}1857 / \\
1864\end{array}$ & 1870 & 1880 & 1885 & 1890 & 1892 & 1893 & 1894 & 1895 & 1896 & 1897 & 1898 & 1899 \\
\hline Associação Tipográfica da Bahia & & 68 & & & & & 70 & & & & & & \\
\hline Centro Operário da Bahia & & & & & & & & 5.000 & & & & & \\
\hline \multicolumn{14}{|l|}{ Mutuaria Rio Branco } \\
\hline \multicolumn{14}{|l|}{ Mutuaria Baiana Pedro II } \\
\hline Sociedade Montepio dos Artífices & & & & & & & 132 & & & & & & \\
\hline Sociedade Bolsa de Caridade & & & & & & 365 & 392 & & & & & & \\
\hline Sociedade Protetora dos Desvalidos & & & & & & & & & 325 & 359 & 391 & 396 & 394 \\
\hline \multicolumn{14}{|l|}{$\begin{array}{l}\text { Associação Geral de Auxílios Mútuos da } \\
\text { Estrada de Ferro do São Francisco }\end{array}$} \\
\hline \multicolumn{14}{|l|}{$\begin{array}{l}\text { Caixa de Aposentadorias e Pensões dos } \\
\text { Funcionários da Estrada de Ferro de } \\
\text { Ilhéus à Conquista }\end{array}$} \\
\hline Sociedade Montepio Geral da Bahia & $\begin{array}{c}1.000 \\
/\end{array}$ & & 220 & 174 & & & 63 & & & & & & \\
\hline $\begin{array}{l}\text { Real Sociedade Portuguesa de } \\
\text { Beneficência } 16 \text { de Setembro }\end{array}$ & $\begin{array}{c}/ \\
1.231\end{array}$ & & & & & & & & & & & & \\
\hline Socíedad Española de Beneficencia & & & & 124 & & & & & & & & & \\
\hline \multicolumn{14}{|l|}{$\begin{array}{l}\text { Associação dos Empregados no } \\
\text { Comércio da Bahia }\end{array}$} \\
\hline Sociedade Beneficência Caixeiral & & & & 88 & & & 31 & & & & 1.075 & 1.027 & 985 \\
\hline $\begin{array}{c}\text { Associação dos Funcionários Públicos do } \\
\text { Estado da Bahia / Caixa de Beneficência } \\
\text { da AFPEB }\end{array}$ & & & & & & & & & & & & & \\
\hline
\end{tabular}

TABELA 7:

NÚMERO DE SÓCIOS DE ALGUMAS ASSOCIAÇÕES DE AUXÍLIO MÚTUO - BAHIA, 1832 -

\begin{tabular}{|c|c|c|c|c|c|c|c|c|c|c|c|}
\hline Sociedade & 1900 & 1901 & 1902 & 1903 & 1904 & 1905 & 1906 & 1907 & 1908 & 1909 & 1910 \\
\hline Associação Tipográfica da Bahia & & & & & 101 & 112 & 125 & 132 & 140 & 144 & 148 \\
\hline Centro Operário da Bahia & & & 4.000 & & 1.945 & & & & & & \\
\hline Mutuaria Rio Branco & & & & & & & & 485 & 420 & & \\
\hline Mutuaria Baiana Pedro II & & & & & & & 200 & 988 & 972 & & \\
\hline Sociedade Montepio dos Artífices & & & & & & & & & & & 139 \\
\hline Sociedade Humanitária dos Artistas & & & & & & & 50 & & & & \\
\hline Sociedade Bolsa de Caridade & & & & & & 1.051 & 1.031 & 1.032 & & 1.027 & \\
\hline Sociedade Protetora dos Desvalidos & & & & & & & & & & 337 & \\
\hline $\begin{array}{l}\text { Associação Geral de Auxílios Mútuos da } \\
\text { Estrada de Ferro do São Francisco }\end{array}$ & 67 & 126 & 453 & 416 & & & & & & & \\
\hline \multicolumn{12}{|l|}{$\begin{array}{l}\text { Caixa de Aposentadorias e Pensões dos } \\
\text { Funcionários da Estrada de Ferro de } \\
\text { Ilhéus à Conquista }\end{array}$} \\
\hline \multicolumn{12}{|l|}{ Sociedade Montepio da Bahia } \\
\hline $\begin{array}{l}\text { Real Sociedade Portuguesa de } \\
\text { Beneficência } 16 \text { de Setembro }\end{array}$ & 1.127 & 1.128 & & & & & 999 & & & 1.004 & 1.025 \\
\hline Socíedad Española de Beneficencia & 700 & & & & & & & 900 & & & 700 \\
\hline $\begin{array}{l}\text { Associação dos Empregados no } \\
\text { Comércio da Bahia }\end{array}$ & & & & & 708 & 708 & & 1.061 & 1070 & & \\
\hline Sociedade Beneficência Caixeiral & 990 & & & 831 & 855 & 700 & 773 & & & & 691 \\
\hline $\begin{array}{c}\text { Associação dos Funcionários Públicos do } \\
\text { Estado da Bahia / Caixa de Beneficência } \\
\text { da AFPEB }\end{array}$ & & & & & & & & & & & \\
\hline
\end{tabular}


TABELA 7:

NÚMERO DE SÓCIOS DE ALGUMAS ASSOCIAÇÕES DE AUXÍLIO MÚTUO - BAHIA, 1832-1930 (Cont.)

\begin{tabular}{|c|c|c|c|c|c|c|c|c|c|c|}
\hline Sociedade & 1911 & 1912 & 1913 & 1914 & 1915 & 1916 & 1917 & 1918 & 1919 & 1920 \\
\hline Associação Tipográfica da Bahia & & & & 190 & 194 & & & & & \\
\hline Centro Operário da Bahia & & & & & & 996 & 996 & 1.033 & 1.046 & 1.114 \\
\hline \multicolumn{11}{|l|}{ Mutuaria Baiana Pedro II } \\
\hline \multicolumn{11}{|l|}{ Sociedade Montepio dos Artífices } \\
\hline Sociedade Bolsa de Caridade & 1.018 & 1.044 & 1.065 & 1.077 & 1.103 & 1.126 & 1.154 & & & 1.264 \\
\hline \multicolumn{11}{|l|}{ Sociedade Protetora dos Desvalidos } \\
\hline \multicolumn{11}{|l|}{$\begin{array}{l}\text { Associação Geral de Auxílios Mútuos da } \\
\text { Estrada de Ferro do São Francisco }\end{array}$} \\
\hline \multicolumn{11}{|l|}{$\begin{array}{c}\text { Caixa de Aposentadorias e Pensões dos } \\
\text { Funcionários da Estrada de Ferro de } \\
\text { Ilhéus à Conquista }\end{array}$} \\
\hline Sociedade Montepio Geral da Bahia & 13 & & & & & & & & & \\
\hline $\begin{array}{l}\text { Real Sociedade Portuguesa de } \\
\text { Beneficência } 16 \text { de Setembro }\end{array}$ & 1.031 & & & & & 1.073 & & 1.078 & & \\
\hline Socíedad Española de Beneficencia & 700 & & & & & & & & & \\
\hline $\begin{array}{l}\text { Associação dos Empregados no } \\
\text { Comércio da Bahia }\end{array}$ & & & & 1.187 & 1.180 & & 1.514 & & 2.109 & \\
\hline Sociedade Beneficência Caixeiral & 743 & & & & 746 & 811 & & & & 715 \\
\hline $\begin{array}{c}\text { Associação dos Funcionários Públicos } \\
\text { do Estado da Bahia / Caixa de } \\
\text { Beneficência da AFPEB }\end{array}$ & & & & & & & & 668 & $821 / 494$ & $864 / 522$ \\
\hline
\end{tabular}

TABELA 7:

NÚMERO DE SÓCIOS DE ALGUMAS ASSOCIAÇÕES DE AUXÍLIO MÚTUO - BAHIA, 1832-1930 (Cont.)

\begin{tabular}{|c|c|c|c|c|c|c|c|c|c|c|}
\hline Sociedade & 1921 & 1922 & 1923 & 1924 & 1925 & 1926 & 1927 & 1928 & 1929 & 1930 \\
\hline Associação Tipográfica da Bahia & & & & 241 & & & & 357 & & \\
\hline \multicolumn{11}{|l|}{ Centro Operário da Bahia } \\
\hline \multicolumn{11}{|l|}{ Mutuaria Baiana Pedro II } \\
\hline Sociedade Montepio dos Artífices & & & & & & 188 & 188 & & 381 & 369 \\
\hline Sociedade Bolsa de Caridade & 1.294 & 1.230 & 1.255 & 1.255 & & & & & & \\
\hline Sociedade Protetora dos Desvalidos & & & 243 & & & & & & & \\
\hline \multicolumn{11}{|l|}{$\begin{array}{l}\text { Associação Geral de Auxílios Mútuos da } \\
\text { Estrada de Ferro do São Francisco }\end{array}$} \\
\hline $\begin{array}{c}\text { Caixa de Aposentadorias e Pensões dos } \\
\text { Funcionários da Estrada de Ferro de } \\
\text { Ilhéus à Conquista }\end{array}$ & & & & & 221 & 249 & 261 & 313 & 330 & 361 \\
\hline \multicolumn{11}{|l|}{ Sociedade Montepio Geral da Bahia } \\
\hline \multicolumn{11}{|l|}{$\begin{array}{c}\text { Real Sociedade Portuguesa de } \\
\text { Beneficência } 16 \text { de Setembro }\end{array}$} \\
\hline Socíedad Española de Beneficência & & & 1.133 & & & & & & & \\
\hline $\begin{array}{l}\text { Associação dos Empregados no Comércio } \\
\text { da Bahia }\end{array}$ & & & 2.030 & & 1.853 & & 2.253 & & 2.902 & 2.575 \\
\hline Sociedade Beneficência Caixeiral & & & 746 & 761 & 873 & & 850 & 978 & & \\
\hline $\begin{array}{c}\text { Associação dos Funcionários Públicos do } \\
\text { Estado da Bahia / Caixa de Beneficência } \\
\text { da AFPEB }\end{array}$ & & & & & & & & & & \\
\hline
\end{tabular}

Fontes: APEB, docs. cit. na tabela 1. 
TABELA 8:

SOCIEDADES MUTUALISTAS E BENEFICENTES GERAIS POR BAIRRO / CIDADE

\begin{tabular}{|c|c|c|c|c|}
\hline Nome & Fundação & Reorganização & P. Notícia & Cidade \\
\hline Montepio da Bahia & 08/10/1851 & & & Salvador \\
\hline $\begin{array}{l}\text { Associação das Senhoras de Caridade (Atual Casa da } \\
\text { Providência) }\end{array}$ & 09/07/1854 & & & Salvador \\
\hline $\begin{array}{l}\text { Montepio Geral da Bahia (Antigo Montepio dos Caixeiros } \\
\text { Nacionais) }\end{array}$ & $22 / 11 / 1857$ & ??/??/1870 & & Salvador \\
\hline S. Médico-Farmacêutica de Beneficência Mútua & ??/12/1866 & & & Salvador \\
\hline Clube Beneficente dos Mártires & 20/01/1891 & & & Salvador \\
\hline Sociedade Beneficente União e Amparo & $02 / 02 / 1893$ & & & Amargosa \\
\hline Sociedade Beneficência Mútua de Brotas & $25 / 06 / 1893$ & & & Salvador \\
\hline Sociedade Beneficente 8 de Dezembro & & & ??/??/1898 & Salvador \\
\hline Sociedade Beneficente de Santana & $29 / 06 / 1899$ & 07/06/1917 & & Salvador \\
\hline Sociedade Beneficente e Musical Recreio do Pilar & $01 / 05 / 1902$ & & & Salvador \\
\hline Liga Beneficente dos Paroquianos da Sé & 07/07/1903 & & & Salvador \\
\hline Sociedade Beneficente de Itapuã & & & 04/07/1903 & Salvador \\
\hline Sociedade dos Desvalidos de Maragogipe & & & 04/07/1903 & Maragogipe \\
\hline S. de B. Socorros Mútuos da Cidade de Lençóis & & & $11 / 10 / 1905$ & Lençóis \\
\hline Sociedade Beneficente União Auxiliadora & 22/04/1906 & 26/03/1916 & & Salvador \\
\hline Mutuaria Baiana Pedro II & $30 / 04 / 1906$ & & & Salvador \\
\hline Socorros Mútuos Rio Branco & 02/05/1906 & & & Salvador \\
\hline Mutuaria Amparo do Lar & & & 08/02/1908 & S. do Bonfim \\
\hline Sociedade Beneficência 2 de Fevereiro & & & $20 / 01 / 1909$ & Salvador \\
\hline Sociedade Beneficente Familiar & & & 06/04/1909 & Salvador \\
\hline Mutuaria Alagoinhense & & & $22 / 04 / 1909$ & Alagoinhas \\
\hline Sociedade Protetora das Desvalidas & & & $10 / 08 / 1910$ & Salvador \\
\hline Beneficência Sempre Viva & & & $26 / 04 / 1911$ & Andaraí \\
\hline Clube Dramático Beneficente Bom-Jesuense & ??/07/1911 & & & $\begin{array}{l}\text { Vila do Bom Jesus } \\
\text { do Rio de Contas }\end{array}$ \\
\hline Sociedade Beneficente Amparo dos Profissionais & & & 20/10/1911 & Salvador \\
\hline Sociedade Beneficente 1ㅇ de Dezembro & & & 04/03/1914 & Salvador \\
\hline Sociedade Defesa e Progresso de Massaranduba & $18 / 08 / 1929$ & & & Salvador \\
\hline
\end{tabular}

Fontes: APEB, docs. cit. na tabela 1. 